\title{
Matera. La città del passato, la città del presente, la città del futuro. II 'Vicinato del Mondo'
}

\author{
Roberto Blasi \\ Maria Federica Lettini \\ Roberto Pedone \\ Margherita Tricarico
}

Abstract

La Città. Essa rappresenta l'espressione della vita quotidiana in tutta la sua dinamicità, la sua evoluzione storica e la sua costruzione architettonica; rappresenta il luogo dove istanza storica e istanza estetica determinano la sua armonia o disarmonia.

II dibattito culturale ed emblematico tra architettura, città e il suo futuro sviluppo è un dibattito teorico, lento e distaccato, che si contrappone al rapido sviluppo urbano. La città non segue più un principio basato su strategie evolutive ma si affida ad un principio più effimero, basato sull'espansione incontrollata e su indipendenti interventi puntuali. Nel corso del secolo scorso, maestri come A. Rossi, R. Venturi, C. Rowe e R. Koolhaas, attraverso i loro studi e i loro pensieri hanno stabilito modelli e focus diventati principio di sperimentazione per le generazioni future. Ciò che accomuna i loro contributi alla teoria della città sono i cosiddetti 'livelli di lettura': una serie di strati tematici sovrapposti l'uno all'altro. Ad esempio, A. Rossi legge la città ricercando i 'fatti urbani' e le loro microstorie come memorie vive, altri come R. Koolhaas, invece, indagano gli 'junkspace' owero le zone residuali della città, gli spazi non progettati. Ciò dimostra l'importanza della scelta di studiare la città scientificamente seguendo una teoria sulla quale sistemare delle ipotesi da verificare. Ipotesi che si tradurranno in esempi di innesti architettonici che con il loro valore etico tenteranno di invertire l'inerzia di una parte di città che sino ad ora appare ferma e poco organica.

Parole chiave

patrimonio urbano, città, riconnettere, riverbero, connessioni.

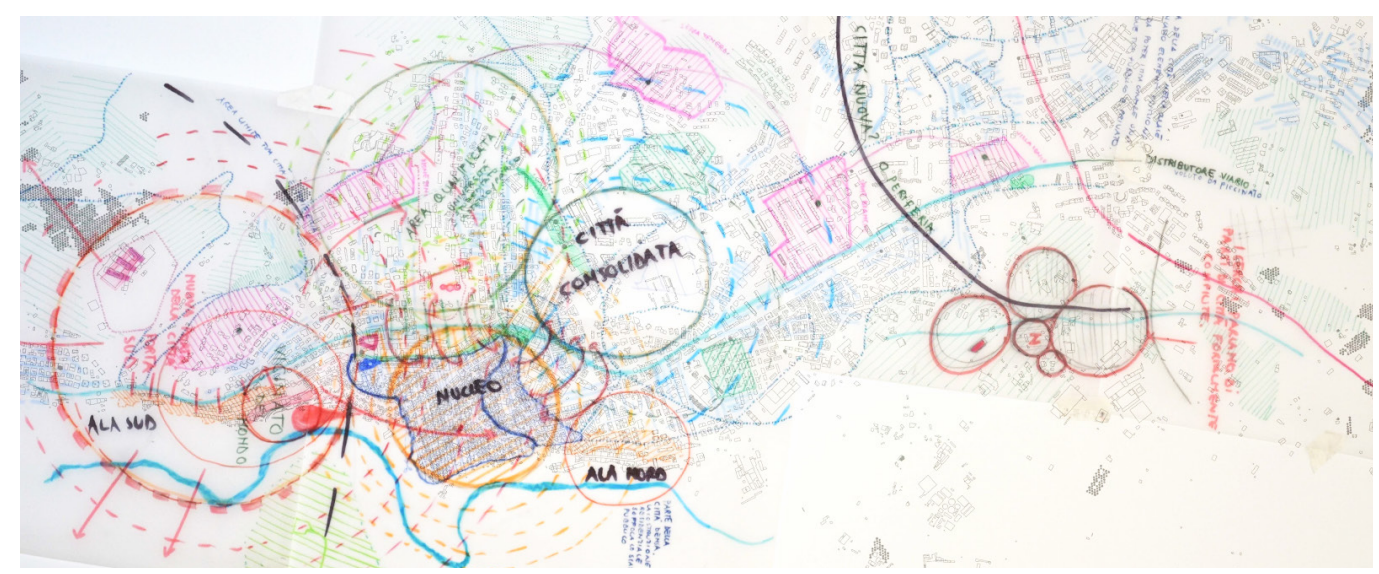


La ricerca affrontata durante il percorso di tesi di laurea in architettura, conseguito a Matera [I], individua una parte di città sulla quale sono state sperimentate alcune idee di recupero e di rigenerazione urbana. L'analisi condotta non interviene puntualmente sulla trama cittadina, ma indaga una porzione più estesa, capace di contaminare strategicamente le diverse realtà limitrofe, dando vita ad un vero e proprio cambiamento (fig. I).

L'area di studio, situata a sud della città di Matera, si presenta come un'area complessa sia nella sua lettura urbanistica-architettonica e sia nella sua natura orografica. Essa posta ai margini del rione Sassi, a ridosso del torrente Gravina, è stata suddivisa in tre aree, diverse per storia, orografia e morfologia: Rione Casalnuovo che rappresenta la parte antica, ricca di grotte ipogee disposte a terrazzamenti; Via Casalnuovo di matrice ottocentesca e Via Lucana, arteria principale della città sulla quale insiste un'edilizia popolare nata dopo la Seconda guerra mondiale. La diversificata natura di queste parti fa sì che si utilizzino tre metodi diversi di studio e conoscenza.

\section{La Tana e l'Eretteo}

Per intervenire in maniera critica è opportuno conoscere le vicende storiche che hanno interessato lo sviluppo di questo brano di città, dai primi insediamenti rupestri sino ai più recenti sviluppi urbanistici. La storia dei luoghi ci permette di evincere quali sono stati i momenti e i passaggi storici che hanno mutato o deviato il normale percorso di crescita di una parte di città. Quali possono essere questi nodi cruciali per gli architetti? La risposta è nascosta nella morfologia abitativa disegnata sul terreno e nel valore espressivo delle architetture realizzate. È in questo che si nascondono le vicende antropologiche e sociologiche di una città, e da qui che si deducono molte dinamiche. Per la natura complessa e stratificata della porzione di città esaminata, dal Rione Casalnuovo a via Lucana, non è stato possibile studiare la storia come semplice somma e cronologia di fatti, ma come narrazione di processi che giustificano le forme e i significati delle diverse realtà urbane con cui ci si è confrontati. Si distinguono due differenti chiavi di lettura: la Tana e l'Eretteo (fig. 2).

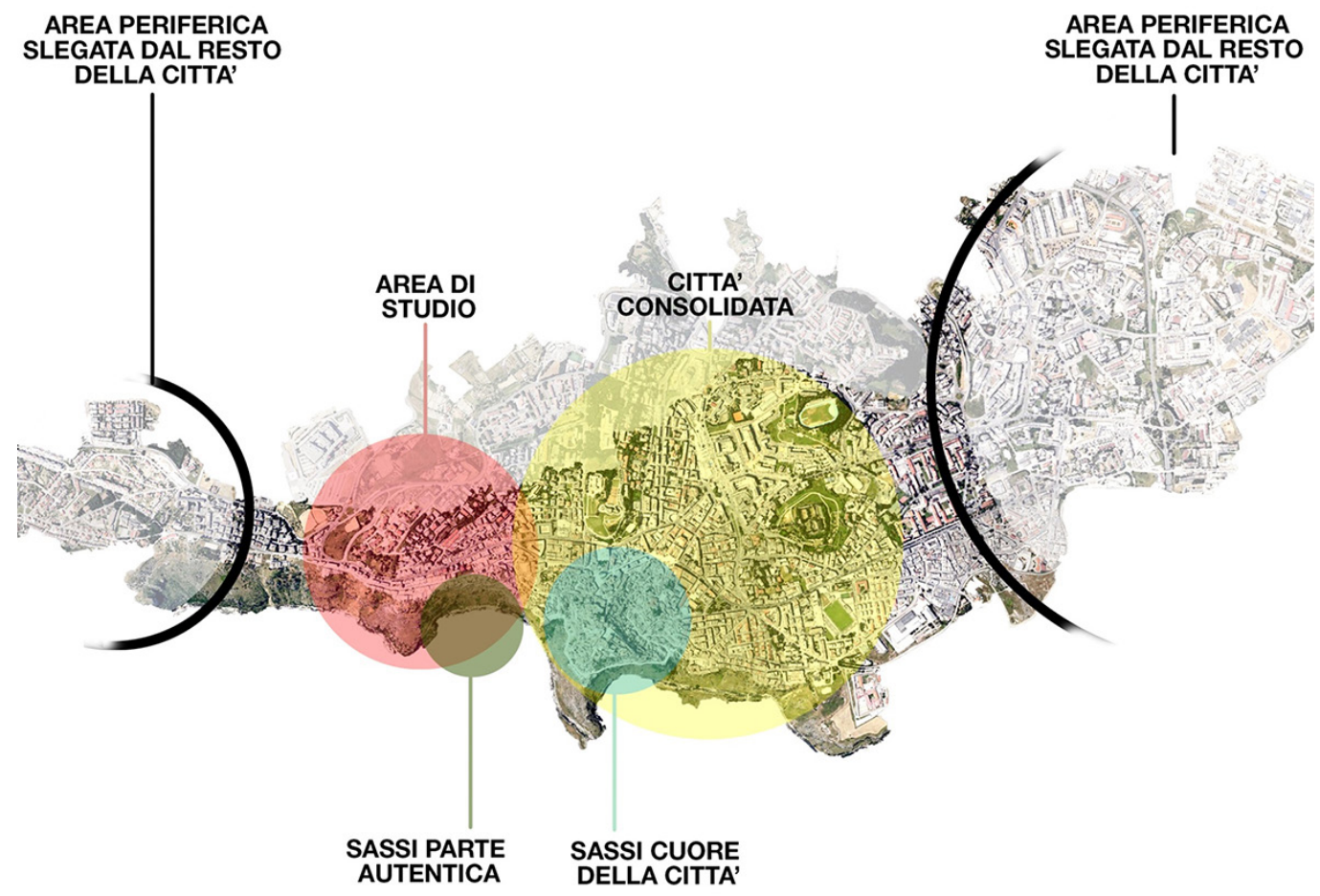


Fig. 2. La Tana, esempio di camera urbana del Rione Casalnuovo (foto di Roberto Pedone).

Fig. 3. L'Eretteo, Via Casalnuovo (foto di Roberto Pedone).
La Tana, termine che allude all'intimità materna, alla culla scavata nella roccia dove migliaia di famiglie sono cresciute, è il racconto della Matera scavata che soffre la mancanza di acqua, l'ostilità della terra e del clima e che fa della privazione un'economia di gestione e sopravvivenza capace di resistere ai secoli (fig. 3).

L'Eretteo, termine che invece allude all'architettura di pregio che connota la volontà politica e sociale e si pone come elemento di cultura nelle nostre città, è la storia della Matera città, che si costruisce nei diversi stili e che si espande oltre i confini di quello che era 'lecito per natura'.
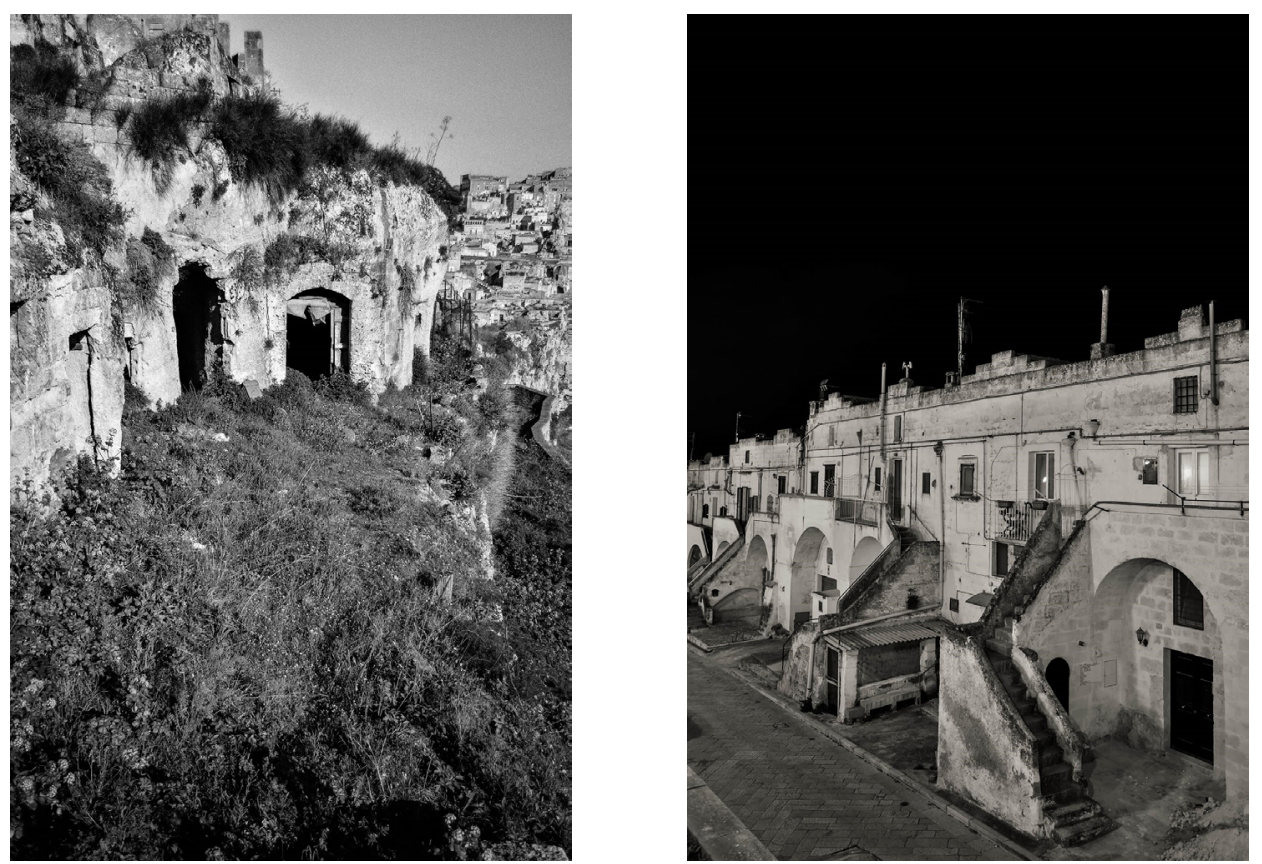

\section{Conoscenza del patrimonio urbano: i nove livelli}

Ci troviamo nella zona sud della città di Matera, precisamente in una porzione delimitata a nord dal prolungamento verso la Gravina della linea di via Bruno Buozzi, a est dal limite naturale del canyon, a sud dal punto in cui Via Casalnuovo incrocia Via Cappuccini comprendendo una zona non urbanizzata su Via Lucana e l'area della futura fermata metropolitana all'inizio di via Montescaglioso, e a ovest dai prospetti di Via Lucana fino all'altezza della chiesa di San Rocco in direzione nord (fig. 4).

Nelle prime fasi di analisi affrontate e dai primi disegni in sezione dell'area emergono non solo informazioni sulla natura visivamente 'in declivio' della zona, ma soprattutto fondamentali considerazioni sulla palese incomunicabilità architettonica e spaziale di due realtà molto vicine: il Piano e i Sassi. La fascia Sassi che scende a terrazzamenti continui verso il torrente è fisicamente divisa dal Piano della 'città nuova' dalla stecca residenziale di via Casalnuovo che rende, in alcuni casi, inaspettata la vista sulla città antica. Si tratta di tre macro-livelli differenti non solo per altimetria, ma per storia e morfologia.

Su Via Lucana nasce l'edilizia di espansione a partire dal '900; essa è la dorsale principale della città dove l'urbanistica di Piccinato si estende con edifici di altezza di 4-5 piani.Via Casalnuovo è il 'livello filtro', chiamato così perché risulta essere di passaggio tra due contesti molto diversi, quello del Piano e quello dei Sassi, quello del nuovo e quello dell'antico. Nel rione Casalnuovo invece, durante i primi sopralluoghi non è apparso semplice contenere visivamente e avere sotto controllo la totalità dello spazio rupestre tra grovigli di cespugli che occludevano le aperture, ripide discese e ambienti interni profondi come radici. II rapporto 
tra i terrazzamenti e gli ingressi era poco immediato e ancor meno visibili i collegamenti tra le diverse quote: c'era un problema di razionalizzazione e ordine che doveva essere affrontato in prima analisi con lo strumento del disegno e del rilievo sul campo. La strategia per dare un 'ordine allo spazio' è quella, una volta elaborati i rilievi di ogni singolo ambiente, di far corrispondere ad ognuno di questi un terrazzamento sulla base dell'ingresso principale ed in ogni caso di riconoscere il singolo livello rispetto al naturale camminamento.

Così, nella totalità, si sono riconosciuti nove livelli: livello 9-via Lucana, livello 8-via Casalnuovo, i livelli dal 7 all' I-rione Casalnuovo (fig. 5).

Per le tre macroaree urbane differenti per elementi, storia e complessità, l'analisi non può essere condotta secondo gli stessi criteri ed aspetti. Per ognuno dei nove livelli si definisce un grado di approfondimento analitico adeguato alle caratteristiche intrinseche dell'area di appartenenza (figg. 5, 6).

Come affermano Gianfranco Caniggia e Gian Luigi Maffei in Lettura dell'edilizia di base gli uomini hanno sempre costruito da sé, senza l'intervento dell'architetto e dell'ingegnere, le proprie case agendo guidati dal patrimonio di nozioni consolidate che caratterizzavano ciascuna delle aree culturali in ciascun momento storico agendo in piena coscienza spontanea (a tale condizione corrisponde la massima parte dei prodotti costruttivi nel passato). Per cui la coscienza spontanea può essere definita come l'attitudine di un soggetto operante ad adeguarsi alle condizioni ereditate, senza mediazioni o scelte complesse (fig. 8).

A Matera il "gesto spontaneo" ha il valore del rapporto tra l'uomo che ha necessità di costruire un ricovero e la roccia scoscesa [Giuffrè, Carocci 1997]. La matrice elementare [Caniggia, Maffei 1984, p. 16I] delle case dei Sassi è proprio la grotta naturale tamponata all'esterno da una parete in muratura: è da qui che ha inizio il lungo processo tipologico [Strappa 1995] come globale susseguirsi dei tipi edilizi nel contesto materano.

Lo studio qui affrontato è frutto di un tentativo di ricostruzione di tale ordine processuale dei tipi edilizi, declinato nell'ambito del tessuto di Via Casalnuovo e del tutto lontano dal vantare alcuna teoria onnicomprensiva della realtà del Casalnuovo e dei Sassi e più vicina ad un esercizio di comprensione ed intuizione delle logiche evolutive delle zone in esame. La definizione dei tipi edilizi nel contesto dei Sassi è individuata nel rapporto tra casa, percorso di accesso e condizioni orografiche (figg. 6, 7). Lungo via Casalnuovo il variare

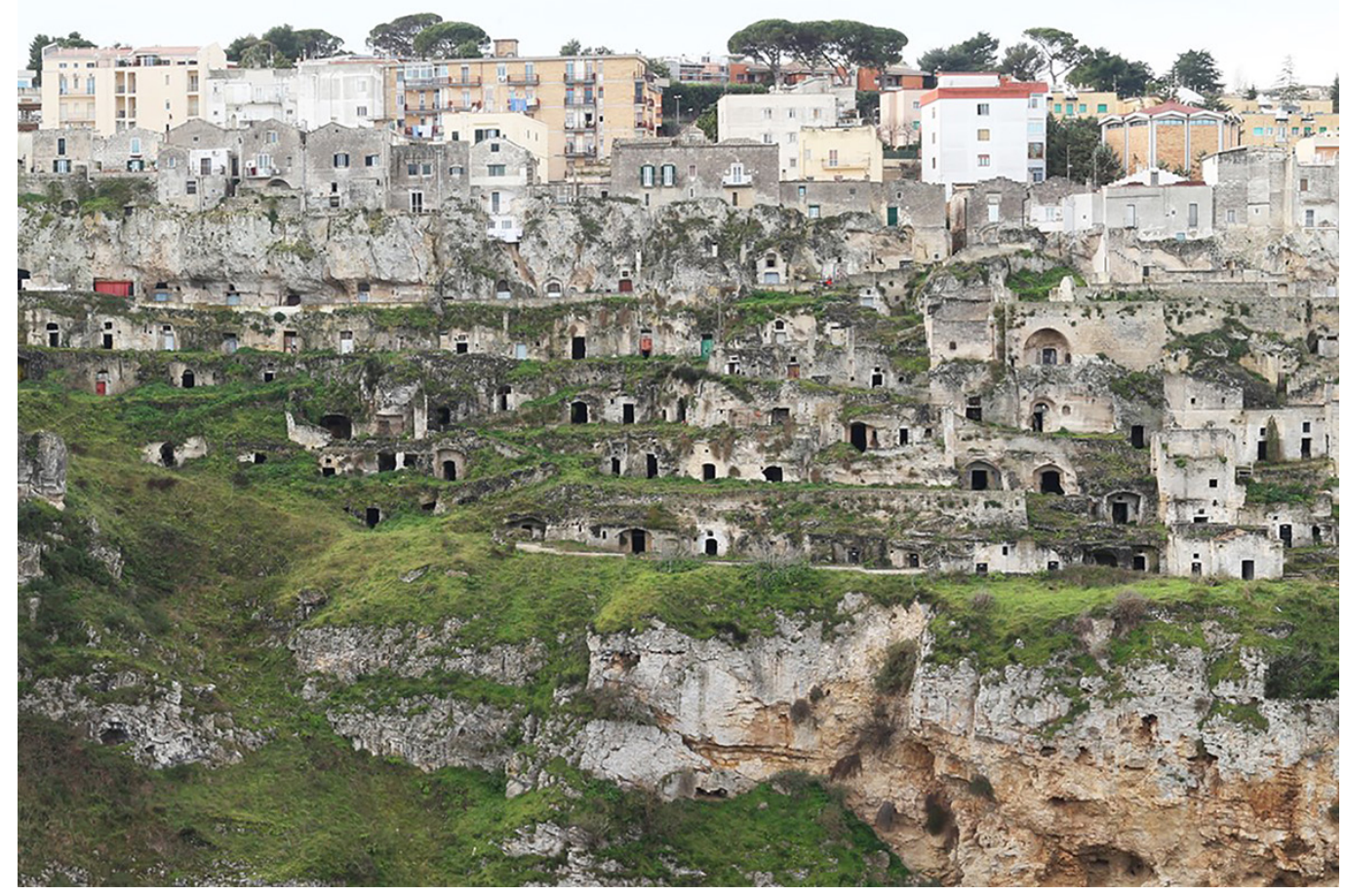


delle pendenze e quindi del rapporto in altezza tra percorso principale-matrice e percorsi successivi-d'impianto [Caniggia, Maffei 1979] determina condizioni sempre diverse di adattamento del tipo (il lamione) (fig. 8). Scoprire le logiche spontanee di adattamento alla terra ha permesso di individuare le zone che all'interno del quartiere interrompono o modificano la regola; le cosiddette discontinuità. In queste discontinuità tipo-morfologiche si fonderà la strategia architettonica dei quattro interventi architettonici riqualificanti: la cavea alle spalle della Chiesa di San Rocco, il vecchio frantoio e gli edifici UNRRA casa a ridosso di via Casalnuovo e via Cappuccini.

\section{Masterplan}

Tra rito e tradizione tutto questo ha il sapore della cultura. Si riparte da qui: il vicinato, molecola dell'insediamento umano nei Sassi. La tipologia abitativa costituita essenzialmente da una corte aperta, come delle braccia poste a cerchio, sulla quale si affacciano un certo numero di ipogei. II vicinato non è solo una forma di aggregazione abitativa, ma uno spazio comune che funziona secondo leggi sociali precise, un luogo in cui ognuno sa come agire per trarre dalla natura il massimo vantaggio grazie ad un insieme di saperi comuni. La comunità ed il sistema urbano nascono, crescono e si evolvono insieme. È questa la filosofia progettuale che ha accompagnato tutto il percorso di sviluppo della ricerca di tesi. Si è voluto estendere enormemente il suo significato: creare sviluppo e crescita riannodando quei fili che la storia ha interrotto (comunità, solidarietà, saggezza locale), facendoci aiutare dallo straordinario potere che l'architettura per sua natura porta con sé. Costruire edifici che poggiano su valori come arte (espressione), cultura (coltivazione) e tradizione (conservazione) (fig. 9).

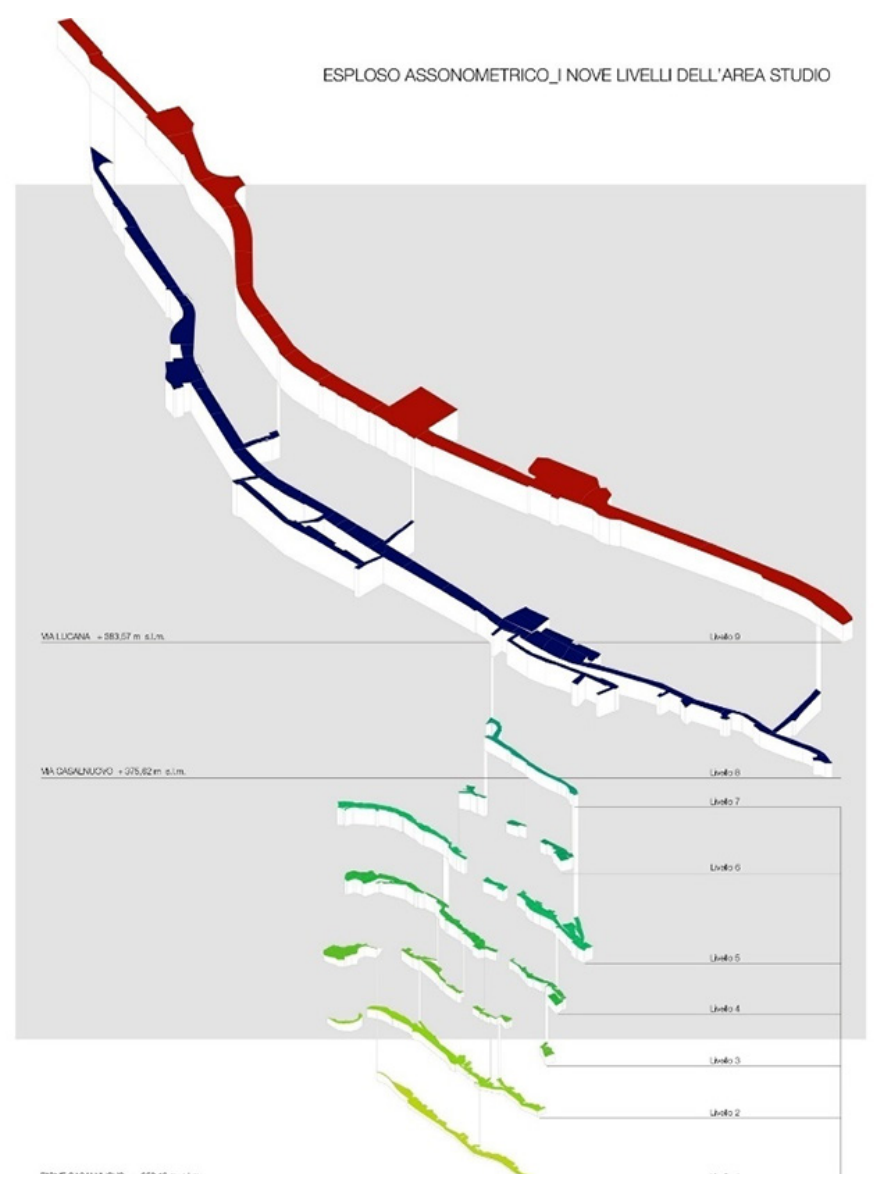




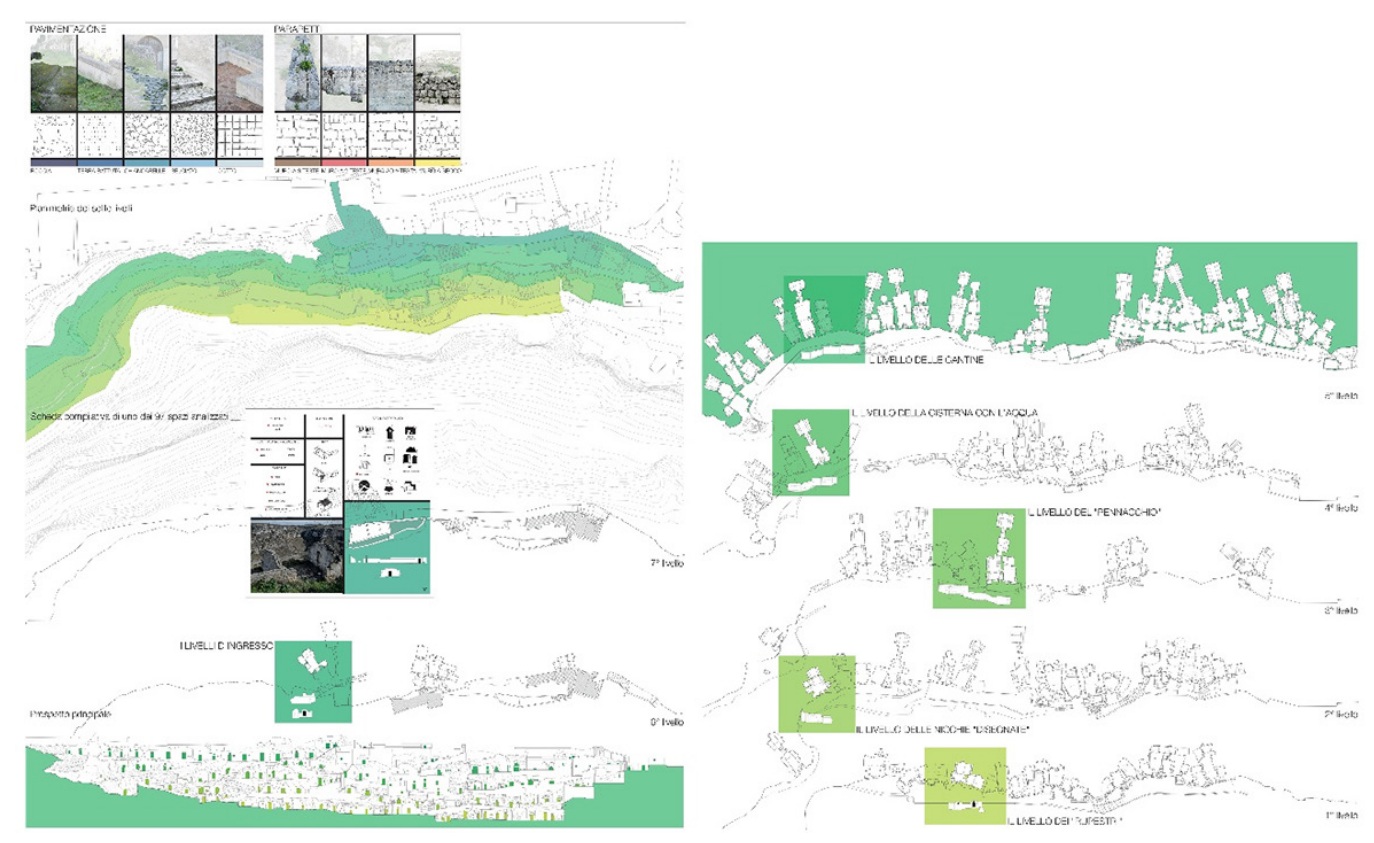

Fig. 6, 7. Schede tipo di studio e analisi, per ogni ambiente presente all'interno del Rione Caveoso.

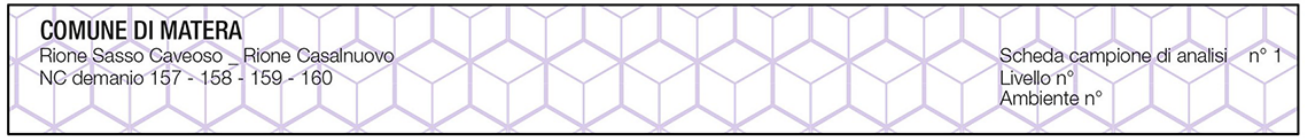

\begin{tabular}{|llll|}
\hline \multicolumn{3}{|l|}{$\begin{array}{l}\text { STATO DI PROPRIETA' DEMANIALE } \\
\text { vioto }\end{array}$} \\
@occupato abusivamente & \\
\hline DATI STEREOMETRICI & & \\
Sup. c. & $219.53 \mathrm{mq}$ & Altezza max & $4.10 \mathrm{~m}$ \\
Vani & 3 & Altezza min & $1.60 \mathrm{~m}$ \\
\hline
\end{tabular}

DESTINAZIONE D'USO PREVALENTE

$\checkmark$ abitazione $\triangle$ cantina

$\checkmark$ stalla $\$$ luogo di meditazione/culto

TIPOLOGIA COSTRUTTIVA

$\nabla$ grotta ambiente costruito $\oplus$ lamione

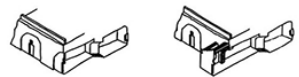

SEGNI PARTICOLARI

D nicchie funzionali $\unlhd$ comignoli
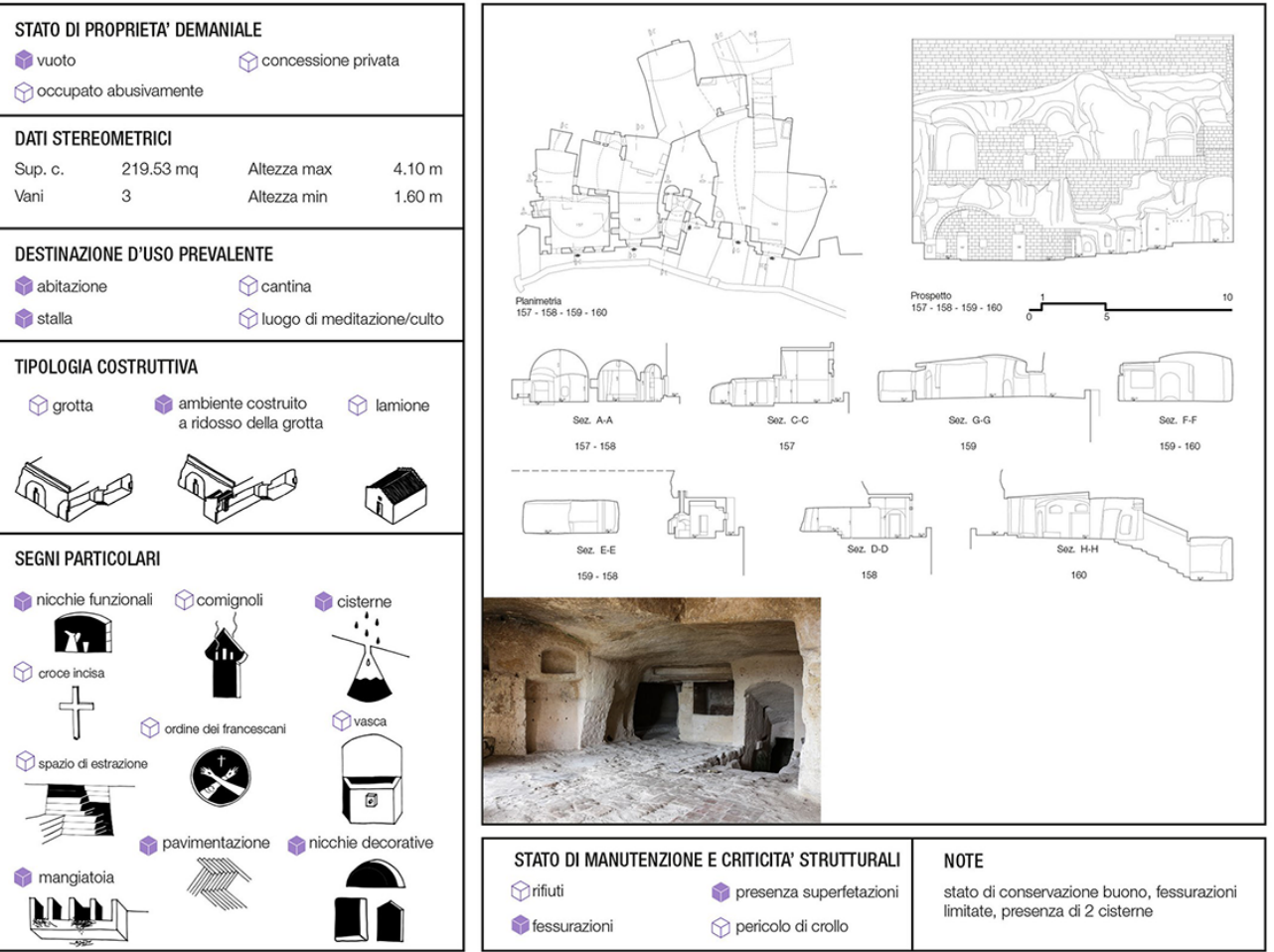
TIPOLOGIE EDILIZIE
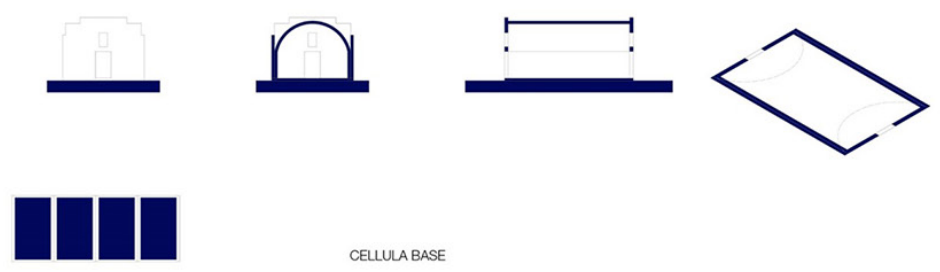

CELUULA BAS
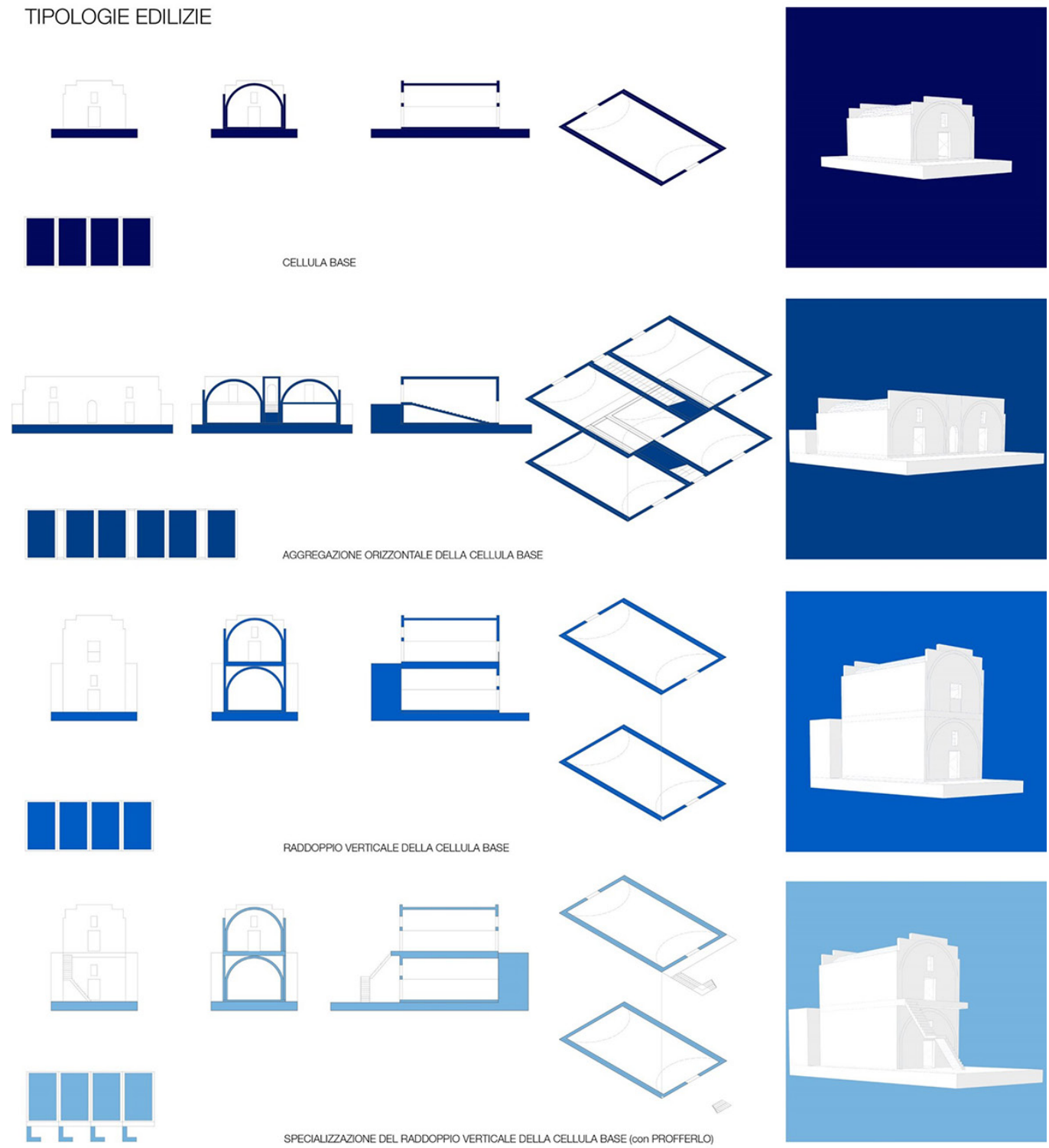

SPECIAUZZAZIONE DEL RADDOPPIO VERTCALE DELLA CELLULA BASE (CON PROFFERLO
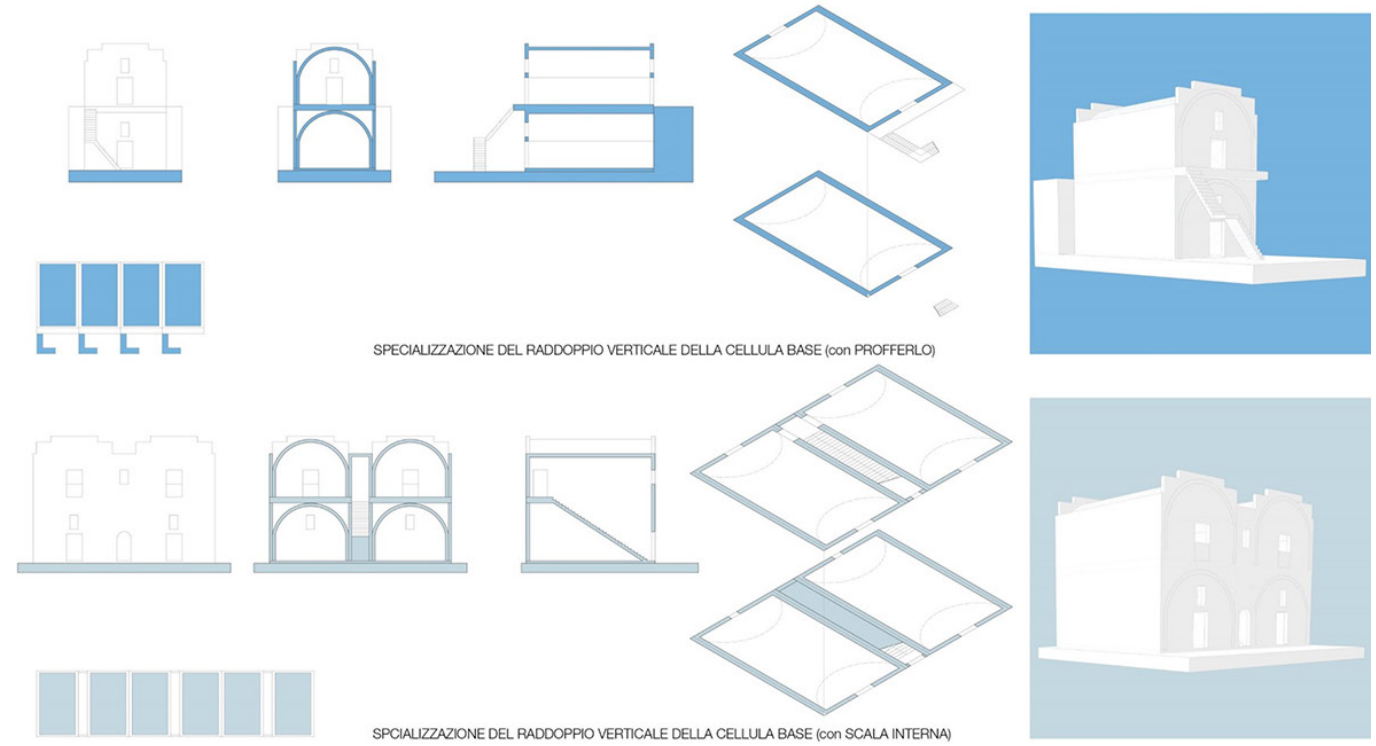
IIVicinato del Mondo. È un modo di stare insieme non più tra poche famiglie, ma tra persone provenienti da luoghi differenti. Non coincide più con l'incavo a ferro di cavallo sul quale si affacciano gli ipogei, ma con l'intera Matera che oggi rappresenta le braccia dell'antico vicinato dei Sassi: la città è fonte di una cultura millenaria dalla quale far scaturire acqua novella. La prima e nuova goccia che potrebbe essere capace di generare l'onda del cambiamento coincide proprio con l'ultima striscia di terrazzamenti a sud del Caveoso, quel lembo dei Sassi ricco dei segni della sua storia. La piccola goccia cade, sposta una certa quantità di volume, genera una perturbazione: un'infinità di onde concentriche che si propagano aumentando man mano il loro diametro. La goccia è sinonimo di acqua, scavo, sistema e comunità, parole sintesi della complessa storia materana. Quattro importanti concetti che dimostrano come l'uomo ha saputo per millenni adattarsi all'ambiente nel rispetto di questo: uomo e natura si compenetrano continuamente (fig. I0).

Allora come riconnettere e ricucire il filo sospeso di Casalnuovo alla trama cittadina? Sono state condotte due strategie progettuali: la prima guarda al flusso esterno-interno e la seconda al flusso interno dalla città a via Casalnuovo.

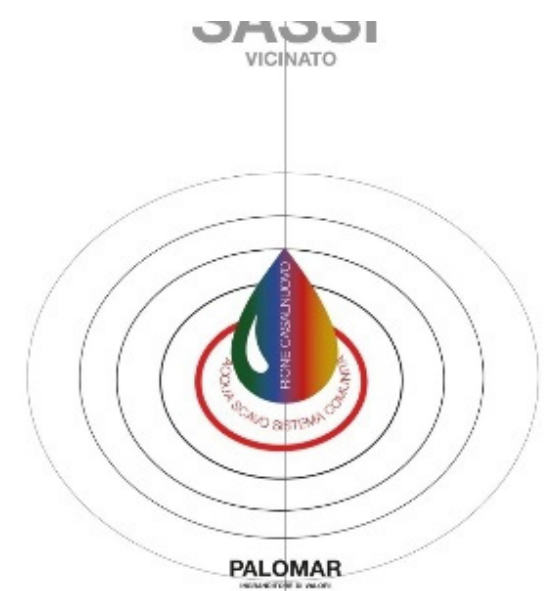

PALOMAR

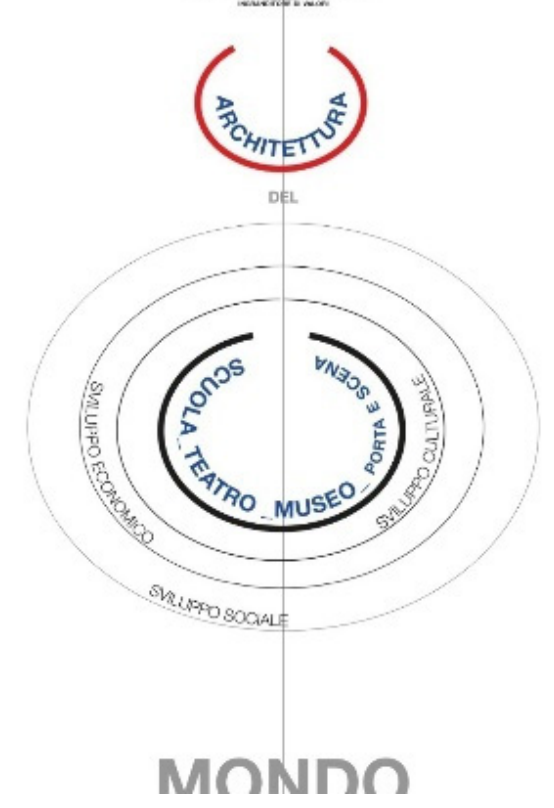




\section{Flusso esterno-interno: La Porta}

Nell'ottica di una futura espansione della città in direzione sud e di un sempre più consistente numero di visitatori, Matera, alleggerendo il carico turistico che approda in Piazza della Visitazione, può trarre beneficio dalla realizzazione di un nuovo ingresso ai Sassi: la porta sud, inizio del percorso delle antiche vallette. Rafforzata dalla futura realizzazione della fermata della linea ferroviaria Appulo-Lucana (all'altezza dell'Ospedale Madonna delle Grazie) e dalla possibile sistemazione a parco dell'area circostante il Villino Bronzini, l'idea di aprire su Via Casalnuovo una porta di accesso ai Sassi, in più rispetto a quelle canoniche del centro, risulta essere strategica, oltre che un'operazione capace di far rientrare quest'ala sud di Matera nelle dinamiche di sviluppo della città. Tra via Lucana e la più bassa Casalnuovo 7,00 $\mathrm{m}$ di dislivello impediscono il passaggio del flusso di persone: la soluzione è attraversare dall'interno la massa che separa nella sua altezza i due piani. Un chiaro asse che immette il flusso delle 'comunità del mondo' direttamente su via Casalnuovo direzionandolo ai Sassi e alla scoperta di questi.

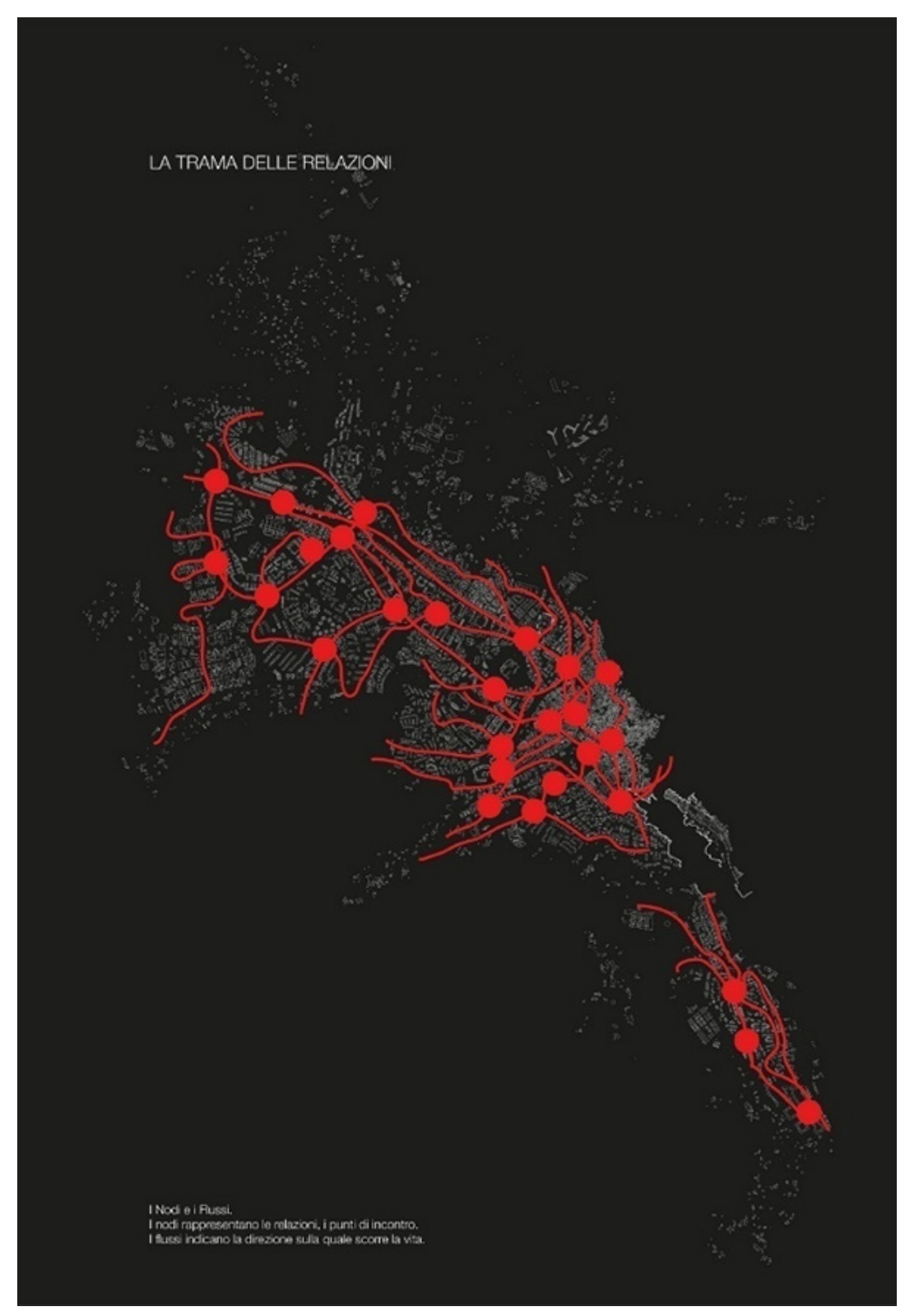




\section{Flusso interno dalla città a Via Casalnuovo: La Scena}

La ricucitura dell'altro estremo del 'filo Casalnuovo' può avvenire intervenendo sulla scena urbana. Via Ridola, cuore pulsante della vita cittadina, è a pochi metri, tuttavia ne sembra distante ed incapace di inglobare la lunga via degli Albanesi al resto della città. Affinché il flusso, ora quello dei visitatori ora quello degli abitanti, sia motivato a spingersi oltre il vecchio grabiglione deve esistere un'attrazione, un motivo che lo porti a prolungare la passeggiata oltre via Ridola. Questo è il principio fondamentale dei progetti Palomar che diventano la scena della nuova passeggiata: numerose botteghe/negozi si fissano al piano terra, le abitazioni si spostano al primo piano in un completamento dei lunghi prospetti della via. II Museo Palomar distribuisce i suoi numerosi accessi, la Scuola di design Palomar riempie il volume del rustico spoglio contaminando l'ex frantoio sottostante e il Teatro Palomar, all'altezza della chiesa di San Rocco, diventa piazza, con lo scopo di creare un'importante cerniera di connessione trasversale. II limite fisico ha un ruolo predominante così principio di progetto diventa la scelta del vuoto disegnando un volume scavato che lascia su via Lucana la sensazione di apertura. Cosi il 'muro edilizio' cade giù e la città moderna si apre al suo passato lasciando all'occhio la possibilità di raggiungere un nuovo orizzonte (fig. I I).

Sono questi progetti che, in accordo con la forma del paesaggio della città e con la sua ricchezza di risorse, diventano una interpretazione architettonica dei valori dell'identità materana.

\section{VIA LUCANA UN MURO SUL PAESAGGIO}
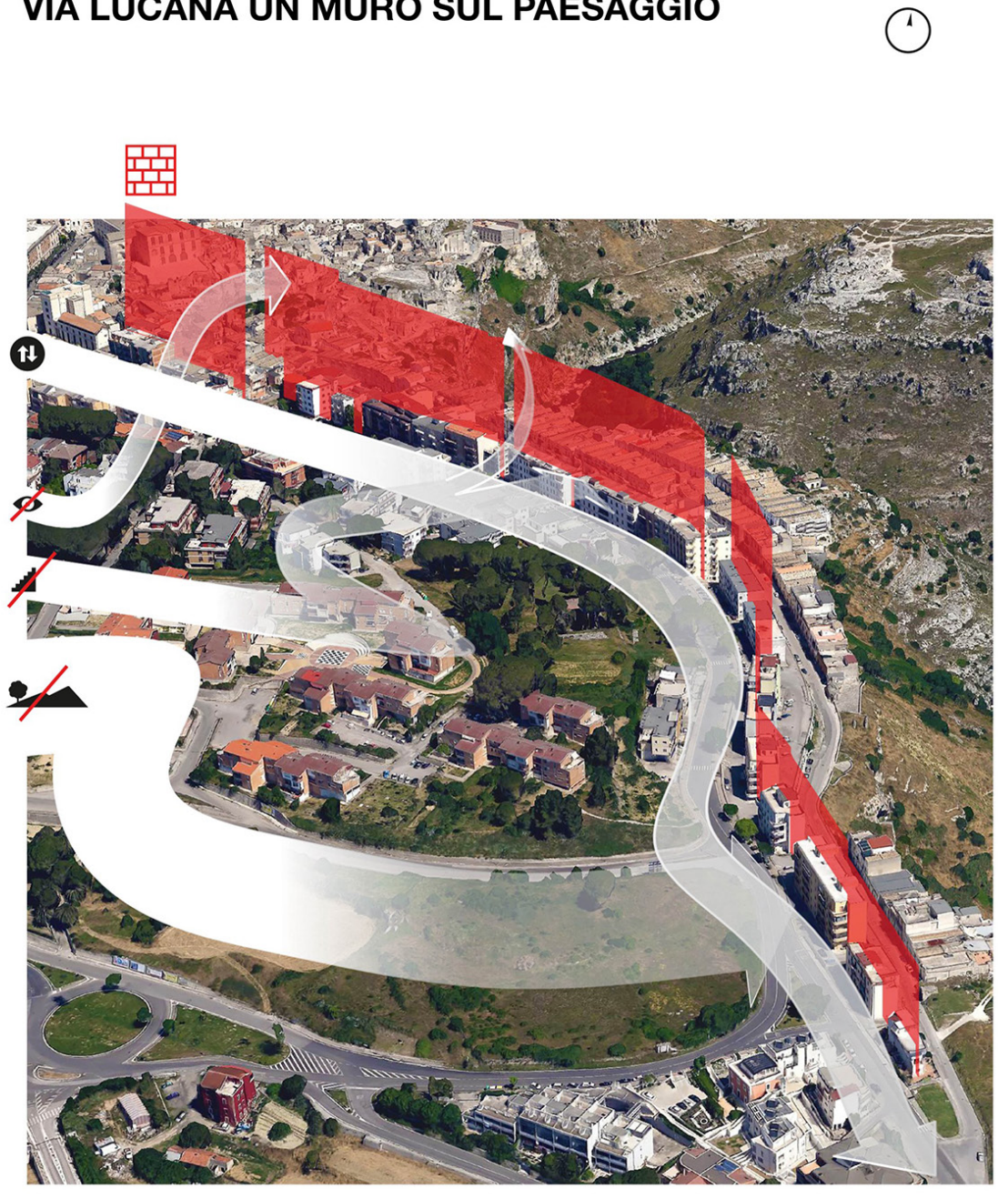
La scena della nuova passeggiata si compone anche del piano orizzontale della strada. II rifacimento della pavimentazione su tutta la via è importante sia nel conferire omogeneità di intervento in un discorso progettuale che parte da un'estremità del percorso e termina all'altra, sia nel ridisegno di un nuovo profilo stradale: il senso di marcia diventa unico e la sezione carrabile da un massimo di larghezza di 7 metri si riduce a 3 lasciando maggiore spazio ai marciapiedi.

La porta e la scena si propongono come due possibili modi di operare nel tentativo sia di ricucire questo brano di città ai lembi delle vicine via Lucana e via Ridola, che direzionare e far vivere alle comunità materana e non un'esperienza ed un insegnamento insiti nel cuore dei Sassi, del Rione Casalnuovo e dei nuovi 'progetti Palomar' che si fanno portatori dello stesso ed antico sistema di valori (fig. 12).

Lo sguardo è rivolto all'intera città, non con l'obiettivo di dare corpo ad una determinata funzione, ma per innescare un vero e proprio cambiamento. In uno scenario in fase di trasformazione, all'alba di una nuova Matera che apre le porte, non solo all'Europa, ma al mondo intero, un insieme di scelte e pensieri più ampi e generali porta inevitabilmente ad uno sviluppo prossimo e permanente della città stessa.

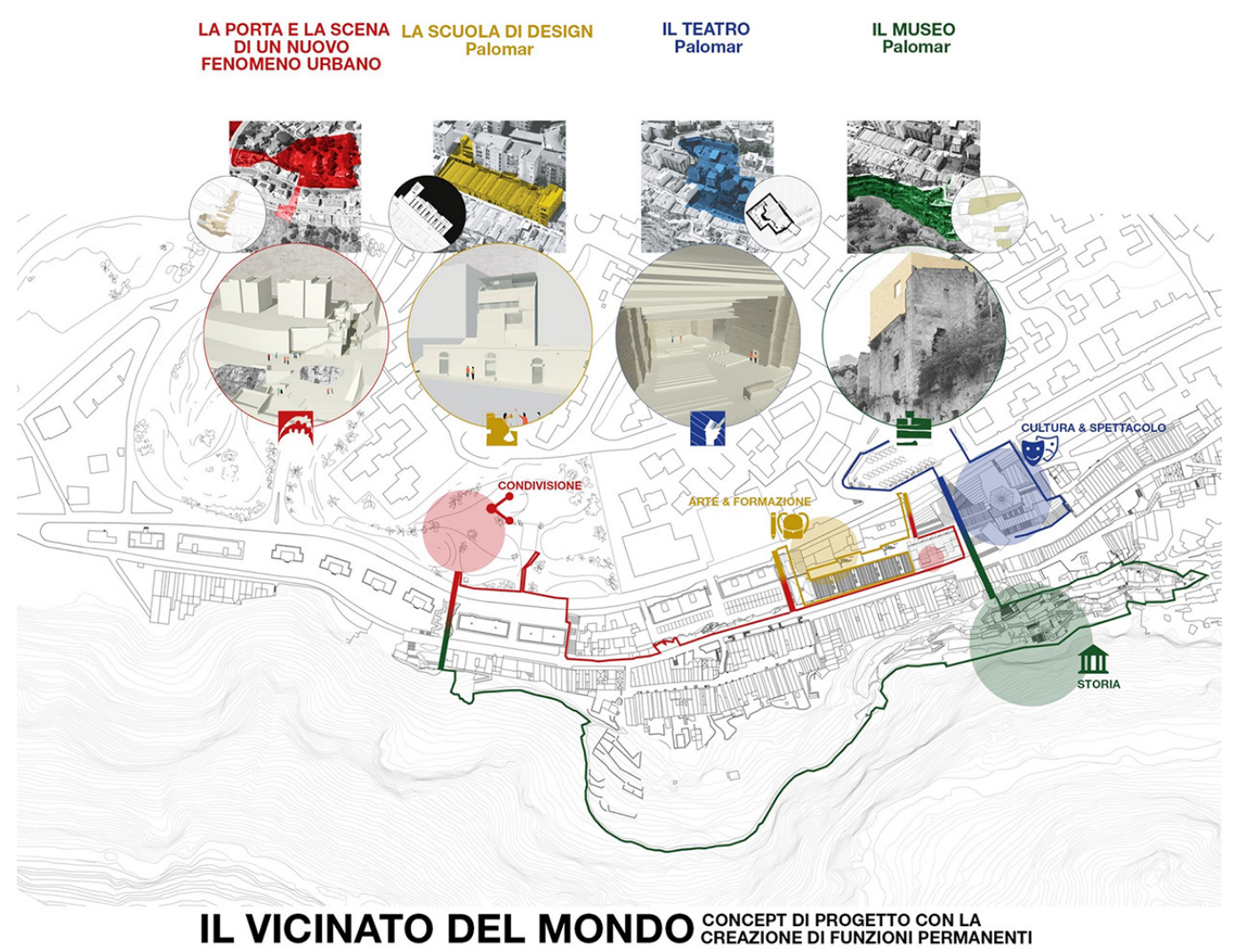

Note

[I] [I] Tesi di laurea magistrale in Architettura. UNIBAS, DiCEM. Laboratorio di laurea: Architettura ed eredità del costruito. II Vicinato del Mondo. Progettazione diffusa nel Patrimonio Urbano: Rione Casalnuovo, via Casalnuovo, via Lucana. Matera. 2015. Relatori interni prof. Antonio Conte, prof. Angela Colonna. Relatori esterni arch. Luigi Acito, arch. Lorenzo Rota. 


\section{Riferimenti bibliografici}

Calvino Italo (1990). Palomar. Milano: Mondadori.

Caniggia Gianfranco, Maffei Luigi (1979). Lettura dell'edilizia di base. Venezia: Marsilio.

Caniggia Gianfranco, Maffei Luigi (1984). Composizione architettonica e tipologia edilizia 2. II progetto nell'edilizia di base. Venezia: Marsilio.

Colonna Angela (20 I5). Genealogia del presente e storiografia dell'architettura. Potenza: Calebasse Edizioni.

Colonna Angela, Fiore Domenico (2012). Idee per un laboratorio partecipato. In Comune di Matera. Matera: i Sassi e il Parco delle chiese rupestri. Verso il piano di Gestione del sito UNESCO.

Colonna Angela, Fiore Domenico (20 I5). I Sassi e il Parco delle chiese rupestri di Matera patrimonio dell'umanità. Piano di Gestione 2014 - 2019. Matera: <http://www.comune.matera.it/piano-di-gestione-unesco>

Conte Antonio (2009). Comunità disegno. Laboratorio a cielo aperto di disegno e rappresentazione nei Sassi di Matera. Milano: Franco Angeli

Conte Antonio (20।4). La città scavata. Paesaggio di patrimoni tradizione e innovazione. Roma: Gangemi Editore.

Giuffrè Antonino, Carocci Caterina (1997). Codice di Pratica per la sicurezza e la conservazione dei Sassi di Matera. Matera: Edizioni La Bautta.

Koolhaas Rem (2006). Junkspace. Macerata: Quodlibet.

Rossi Aldo (2009). L'autobiografia scientifica. Milano: il Saggiatore.

Rossi Aldo, (2019). L'architettura della città. Milano: il Saggiatore.

Rota Lorenzo (20 I I). Matera Storia di una Città. Matera: Studiogiannatelli.

Strappa Giuseppe (1995). Unità dell'organismo architettonico, Note sulla formazione e trasformazione dei caratteri degli edifici. Bari: Edizioni Dedalo

\section{Autori}

Roberto Blasi, Università degli Studi della Basilicata, roberto.blasi@unibas.it

Maria Federica Lettini, Università degli Studi della Basilicata, federicalettini@gmail.com

Roberto Pedone, Università degli Studi della Basilicata, roberto, pedone@unibas.it

Margherita Tricarico, Università degli Studi della Basilicata, margherita.tricarico@unibas.it

Per citare questo capitolo: Blasi Roberto, Lettini Maria Federica, Pedone Roberto, Tricarico Margherita (2020). Matera. La città del passato, la città del presente, la città del futuro. IIVicinato del Mondo/Matera. The city of the past, the city of the present, the city of the future.'IIVicinato del Mondo. In Arena A., Arena M., Brandolino R.G., Colistra D., Ginex G., Mediati D., Nucifora S., Raffa P. (a cura di). Connettere. Un disegno per annodare e tessere. Atti del $42^{\circ}$ Convegno Internazionale dei Docenti delle Discipline della Rappresentazione/Connecting. Drawing for weaving relationships. Proceedings of the 42th International Conference of Representation Disciplines Teachers. Milano: FrancoAngeli, pp. 933-956. 


\title{
Matera. The City of the Past, the City of the Present, the City of the Future. 'Il Vicinato del Mondo'
}

\author{
Roberto Blasi \\ Maria Federica Lettini \\ Roberto Pedone \\ Margherita Tricarico
}

\section{Abstract}

The City. It represents the expression of everyday life in all its dynamism, its historical evolution and its architectural construction; it represents the place where historical and aesthetic instance determine its harmony or disharmony.

The cultural and emblematic debate between architecture, city and its future development is a theoretical debate, slow and detached, which is opposed to the rapid urban development. The city doesn't longer follows a principle based on evolutionary strategies but relies on a more ephemeral principle, based on uncontrolled expansion and independent punctual interventions. During the last century, masters like A. Rossi, R. Venturi, C. Rowe and R. Koolhaas, throughout their studies have established models and focuses that have become a principle of experimentation for future generations. What their contributions to the theory of the city have in common are the so-called 'reading levels': a series of thematic layers superimposed on each other. For example, A. Rossi reads the city by searching for 'urban facts' and their micro-stories as living memories, others like R. Koolhaas, on the other hand, investigate 'junkspace', that is the residual areas of the city, the unplanned spaces. This demonstrates the importance of the choice to study the city scientifically by following a theory on which to arrange hypotheses to be verified. Hypotheses that will be translated into examples of architectural grafts that with their ethical value will try to reverse the inertia of a part of the city that until now appears firm and not very organic.

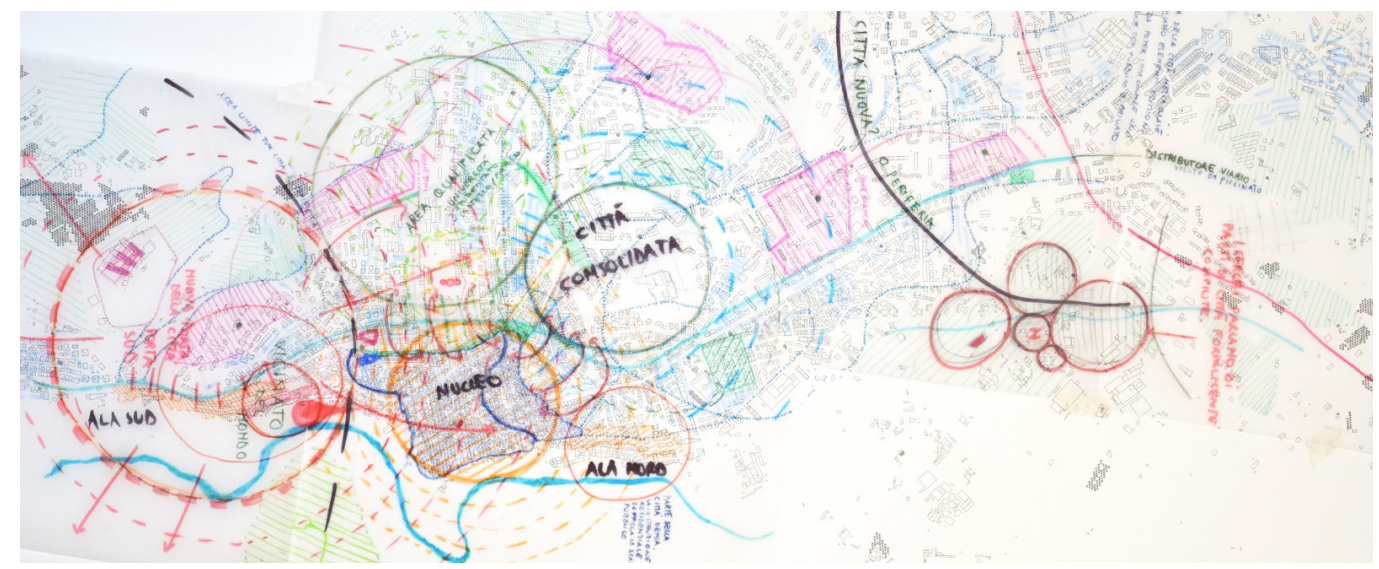


The research addressed during the thesis in architecture, obtained in Matera, one identifies a part of the city on which some ideas of recovery and urban regeneration have been experimented. The analysis carried out does not intervene punctually on the city plot, but investigates a larger portion, able to strategically contaminate the different neighbouring realities, giving rise to a real change. (fig. I).

The study area, located south of the city of Matera, appears as a complex area both in its urban-architectural interpretation and in its orographic nature. It is located on the edge of the Sassi district, close to the Gravina torrent, and has been divided into three areas, different in terms of history, orography and morphology: Casalnuovo district, which represents the ancient part, rich in underground caves arranged on terraces; Via Casalnuovo, a 19th century street, and Via Lucana, the main artery of the city on which there is a social housing system built after the Second World War. The diversified nature of these parts means that three different methods of study and knowledge are used.

\section{LaTana e l'Eretteo}

In order to intervene in a critical way, it is appropriate to know the historical events that have affected the development of this piece of the city, from the first rock settlements to the most recent urban developments. The history of the places allows us to understand the moments and the historical passages that have changed or deviated the normal growth path of a part of the city. What can these crucial nodes be for architects? The answer is hidden in the living morphology drawn on the ground and in the expressive value of the architectures created. It is in this that the anthropological and sociological events of a city are hidden, and from this that many dynamics can be deduced. Due to the complex and stratified nature of the portion of the city examined, from Rione Casalnuovo to Via Lucana, it was not possible to study history as a simple sum and chronology of facts, but as a narrative of processes that justify the forms and meanings of the different urban realities we have been confronted with. Two different interpretations can be distinguished: La Tana e l'Eretteo (fig. 2).

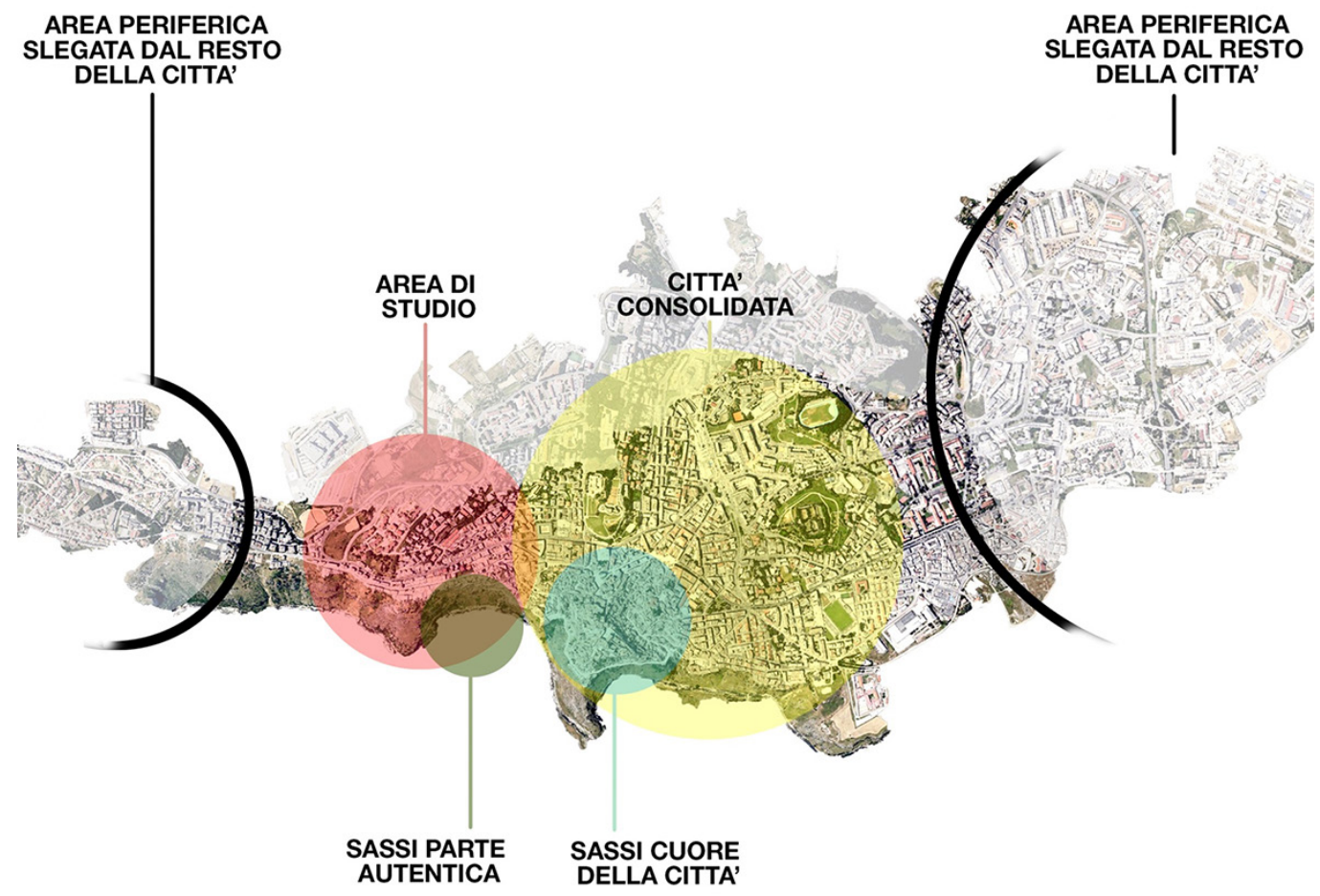


La Tana, a term that alludes to maternal intimacy, to the cradle dug into the rock where thousands of families grew up, is the story of the dug-out Matera that suffers from the lack of water, the hostility of the land and the climate and that makes deprivation an economy of management and survival capable of withstanding the centuries (fig. 2).

L'Eretteo, a term that instead alludes to the valuable architecture that denote the political and social will and is an element of culture in our cities, is the history of Matera city, which is built in different styles and expands beyond the boundaries of what was 'lawful by nature'.

Fig. 2. La Tana, an example of an urban chamber in the Casalnuovo distric (photo by Roberto Pedone)

Fig. 3. L'Eretteo, Via Casalnuovo (photo by Roberto Pedone).
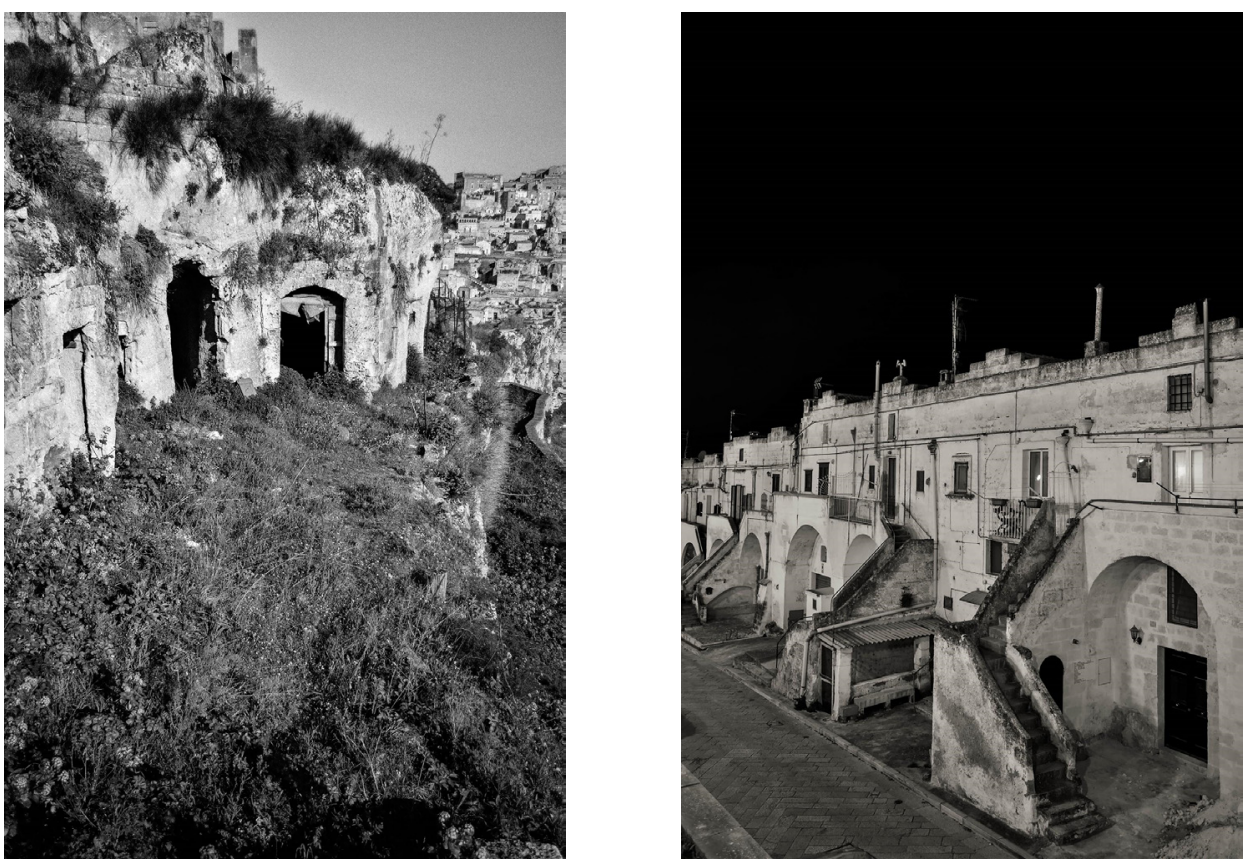

\section{Knowledge of urban heritage: the nine levels}

We are located in the southern area of the city of Matera, precisely in a portion bounded to the north by the extension of the line of Via Bruno Buozzi towards the Gravina, to the east by the natural boundary of the canyon, to the south by the point where Via Casalnuovo crosses Via Cappuccini including a non-urbanized area on Via Lucana and the area of the future metro station at the beginning of Via Montescaglioso, and to the west by the elevations of Via Lucana up to the church of San Rocco to the north (fig. 4).

In the first phases of analysis and from the first section drawings of the area, not only information on the visually "sloping" nature of the area emerges, but also above all fundamental considerations on the obvious architectural and spatial incommunicability of two very close realities: the Piano and the Sassi. The Sassi strip of land that descends on continuous terraces towards the torrent is physically divided from the Piano della 'new city' by the residential slat of Via Casalnuovo, which in some cases makes the view of the ancient city unexpected. These are three different macro-levels not only for altimetry, but for history and morphology. The building of expansion from ' 900 was born on Via Lucana; it is the main ridge of the city where the urban planning of Piccinato extends with buildings of 4-5 floors high. Via Casalnuovo is the filter level, so called because it is a passage between two very different contexts, that of the one of the Piano and the one of the Sassi, that of the new and that of the old. In the Casalnuovo district, on the other hand, during the first inspections, it did not seem easy to visually contain and control the entire rocky space between tangles of bushes that occluded the openings, steep descents and internal environments as deep as roots. 
The relationship between the terraces and the entrances was not very immediate and the connections between the different elevations were even less visible: there was a problem of rationalization and order that had to be faced in the first analysis with the tool of drawing and surveying in the field. The strategy to give an "order to the space" is once the reliefs of each single environment have been elaborated, to make each of them correspond to a terrace on the basis of the main entrance and in any case to recognize the single level with respect to the natural walkway.

Thus, in total, nine levels were recognized: level 9-Via Lucana, level 8-Via Casalnuovo, levels 7 to I-rione Casalnuovo (fig. 5).

For the three urban macro-areas that are different in elements, history and complexity, the analysis cannot be conducted according to the same criteria and aspects. For each of the nine levels, it is defined a degree of analytical analysis appropriate to the intrinsic characteristics of the area. (figs. 6, 7)

As Gianfranco Caniggia and Gian Luigi Maffei say in Lettura dell'edilizia di base men have always built their houses by themselves, without the intervention of the architect and the engineer, acting guided by the heritage of consolidated notions that characterized each of the cultural areas in each historical moment acting in full spontaneous consciousness (this condition corresponds to the majority of building products in the past). Therefore, spontaneous consciousness can be defined as the attitude of an operating subject to adapt to inherited conditions, without mediation or complex choices (fig. 8).

In Matera the 'spontaneous gesture' has the value of the relationship between the man who needs to build a shelter and the steep rock [2]. The elementary matrix [3] of the houses of the Sassi is the natural cave enclosed outside by a masonry wall: it is from here that the long typological process begins[4] as a global succession of building types in the Matera context. The study here is the result of an attempt to reconstruct this procedural order of building types, declined within the fabric of Via Casalnuovo and completely far from boasting any all-encompassing theory of the reality of Casalnuovo and the Sassi and closer to an exercise in understanding and intuition of the evolutionary logic of the areas under examination.

The definition of building types in the context of the Sassi is identified in the relationship between house, access path and orographic conditions (figs. 6, 7). Along via Casalnuovo the

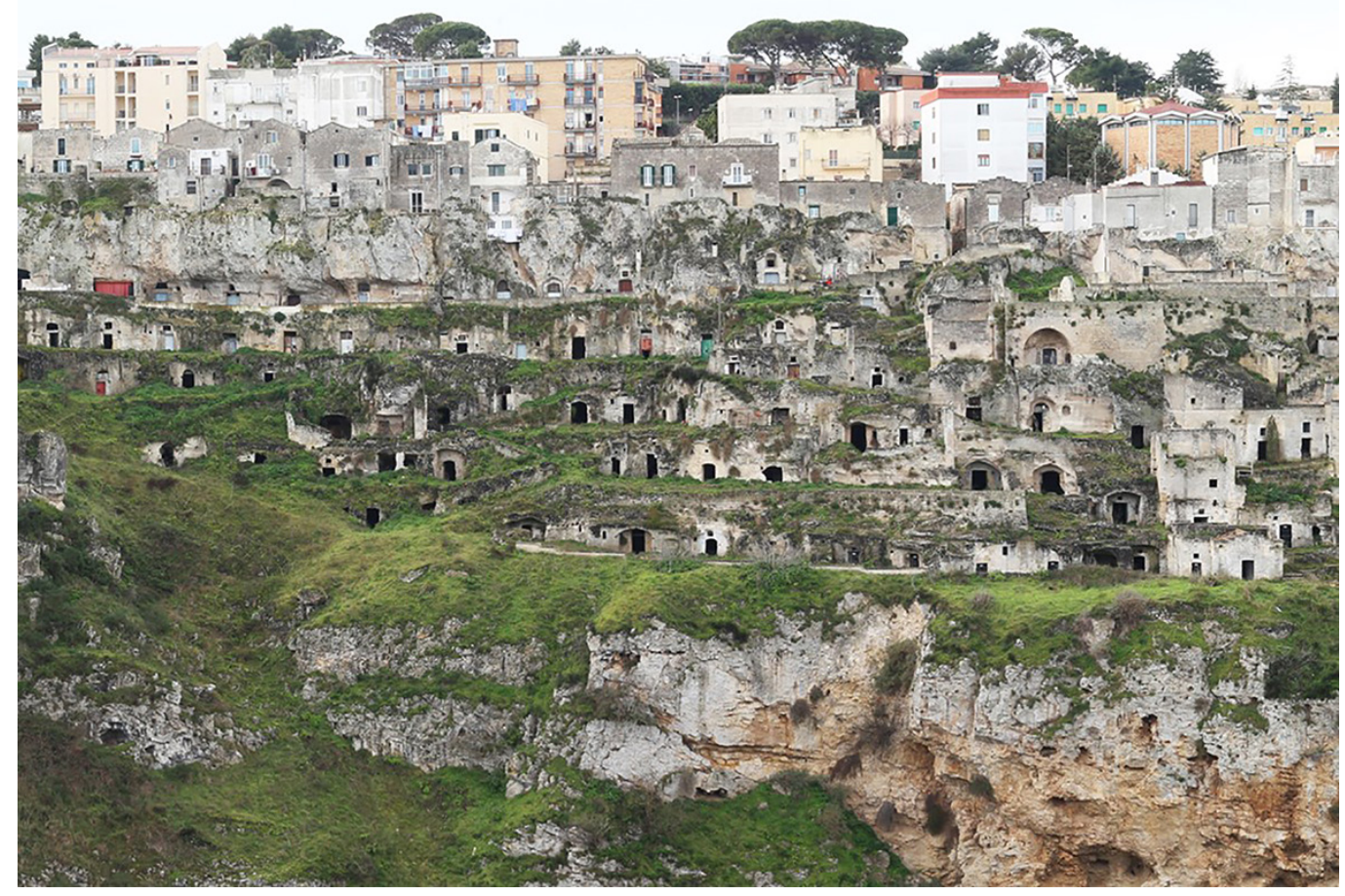


variation of the slopes and therefore of the ratio in height between the main path-matrix and the subsequent paths of the plant 5 determines always different conditions of adaptation of the type (the lamione) (fig. 8). Discovering the spontaneous logics of adaptation to the earth has made it possible to identify the areas within the district that interrupt or modify the rule; the so-called discontinuities. In these morphological discontinued types will merge the architectural strategy of the four requalifying architectural interventions: the cavea behind the Church of San Rocco, the old oil mill and the UNRRA house buildings close to via Casalnuovo and via Cappuccini.

\section{The Masterplan}

Between ritual and tradition all this has the flavour of culture. We start from here: the neighbourhood, a molecule of human settlement in the Sassi. The housing typology essentially consists of an open courtyard, like arms placed in a circle, overlooked by a number of hypogea. Neighbourhood is not only a form of housing aggregation, but a common space that works according to precise social laws, a place where everyone knows how to act in order to take maximum advantage of nature thanks to a set of common knowledge. The community and the urban system are born, grow and evolve together.This is the design philosophy that has accompanied the entire development of the thesis research. We wanted to extend its meaning enormously: to create development and growth by reknotting those threads that history has interrupted (community, solidarity, local wisdom), making us help by the extraordinary power that architecture by its nature brings with it. To build buildings that are based on values such as art (expression), culture (cultivation) and tradition (conservation). (fig. 9).

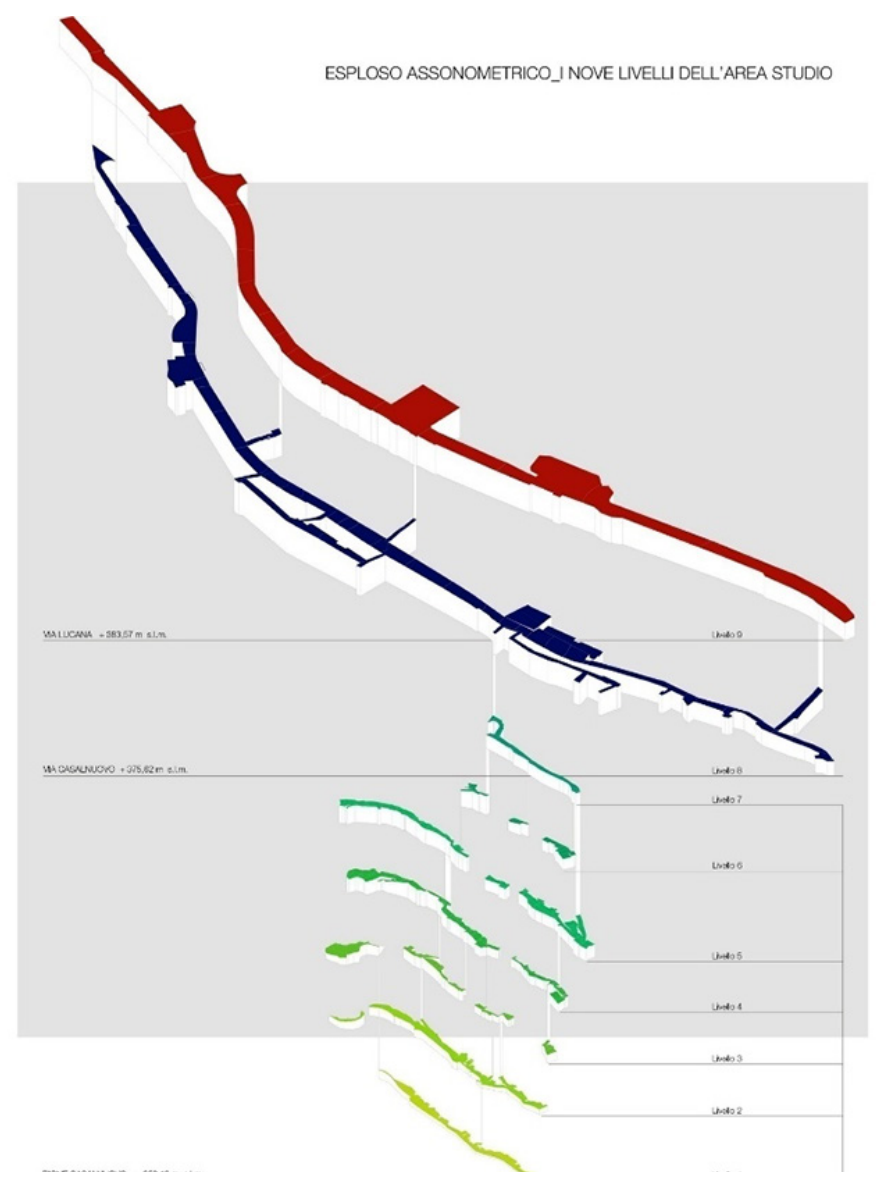



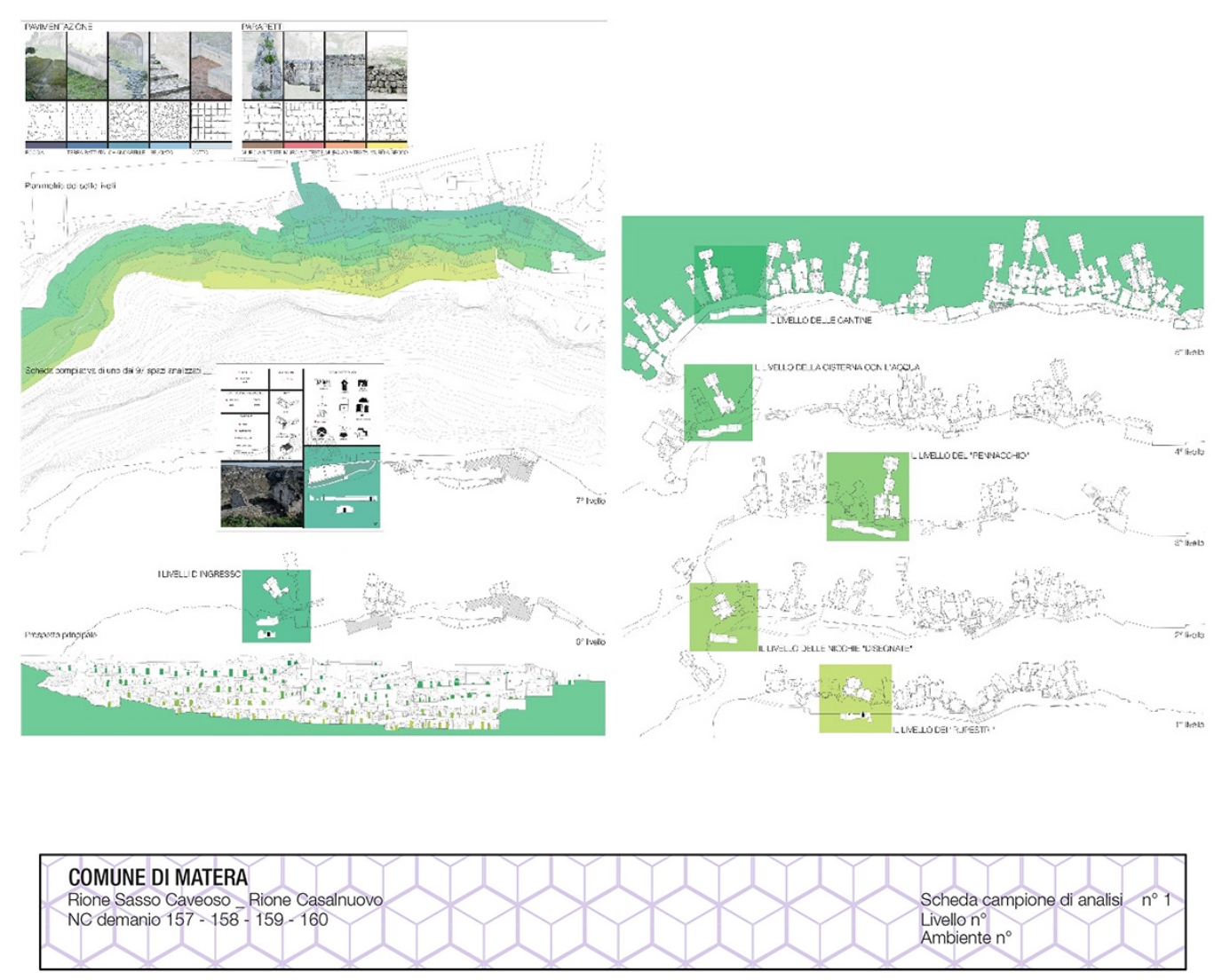

\begin{tabular}{|llll|}
\hline \multicolumn{2}{|l|}{ STATO DI PROPRIETA' DEMANIALE } \\
vuoto \\
Soccupato abusivamente
\end{tabular}

DESTINAZIONE D'USO PREVALENTE

$\checkmark$ abitazione $\theta$ cantina

$\checkmark$ stalla $\quad$ luogo di meditazione/culto

TIPOLOGIA COSTRUTTIVA

$\nabla$ grotta ambiente costruito $\oplus$ lamione

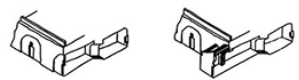

SEGNI PARTICOLARI

S nicchie funzionali $\$$ comignoli
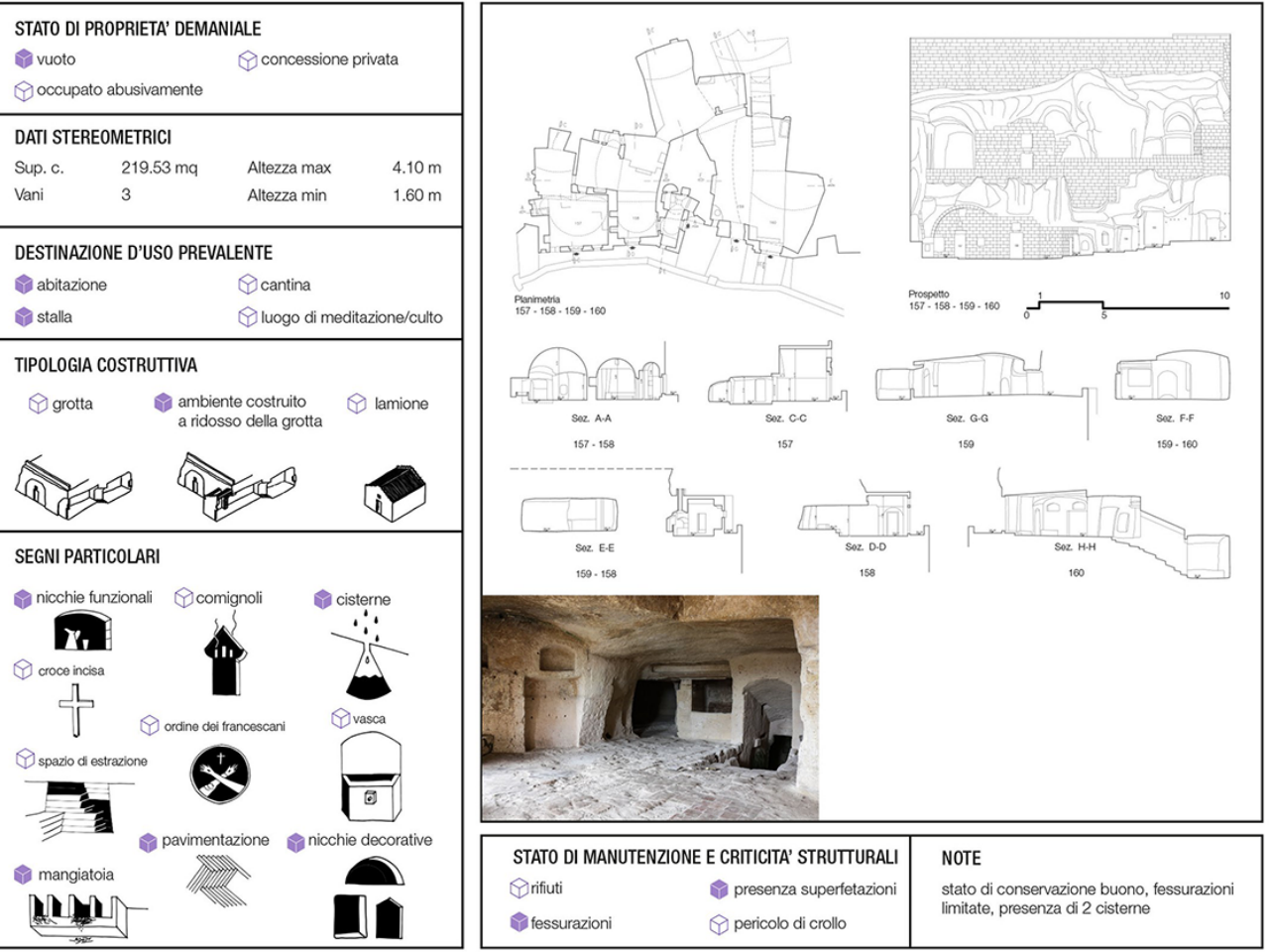
TIPOLOGIE EDILIZIE

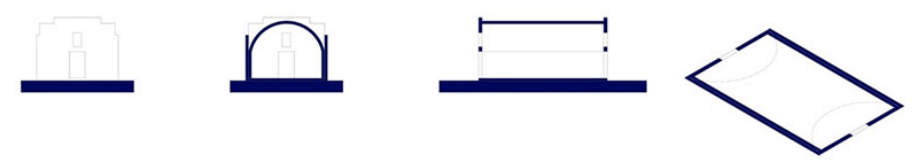

CELUULA BAS
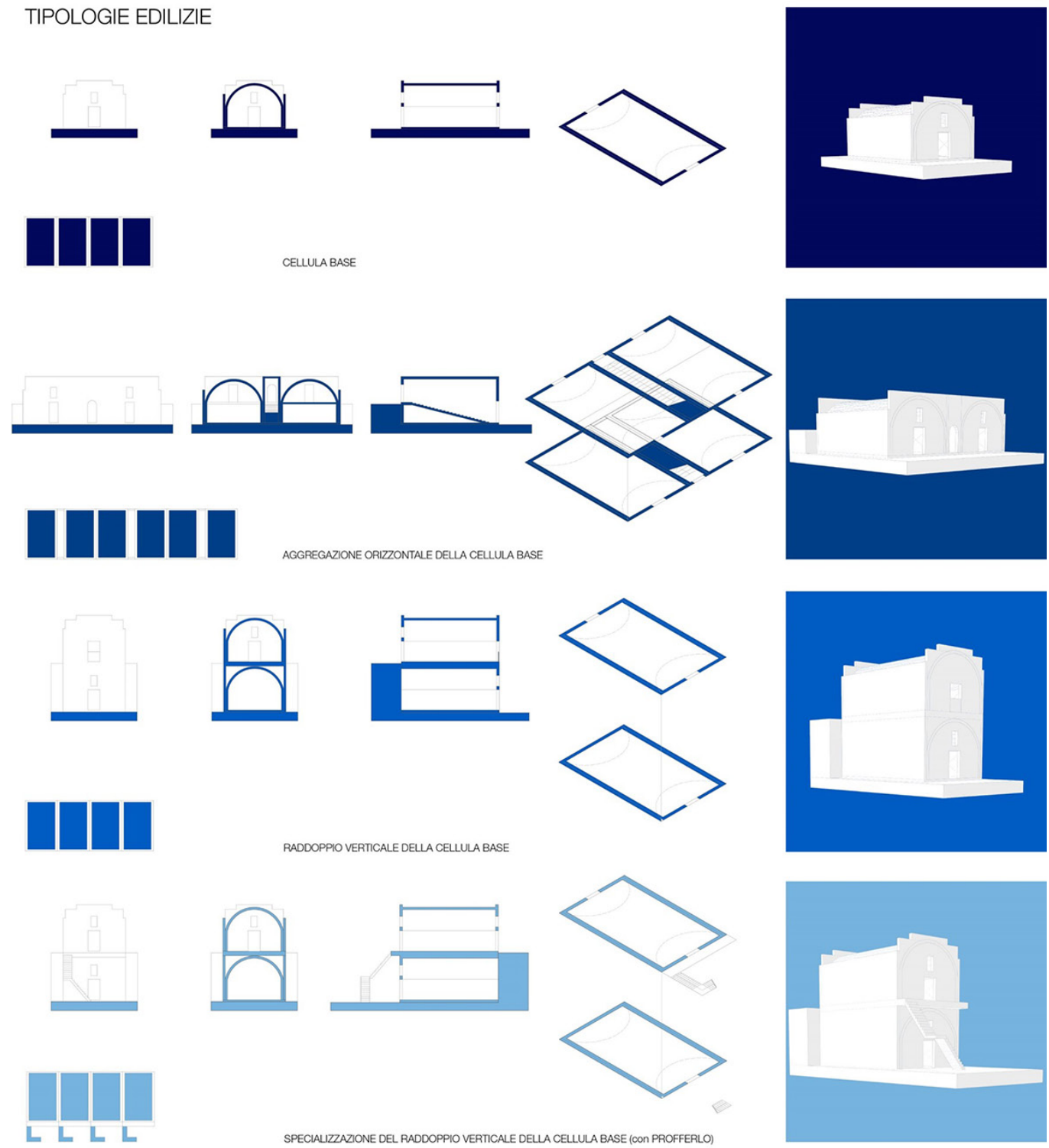

SPECIAUZZAZIONE DEL RADDOPPIO VERTICALE DELLA CELUULA BASE (CON PROFFERLO)
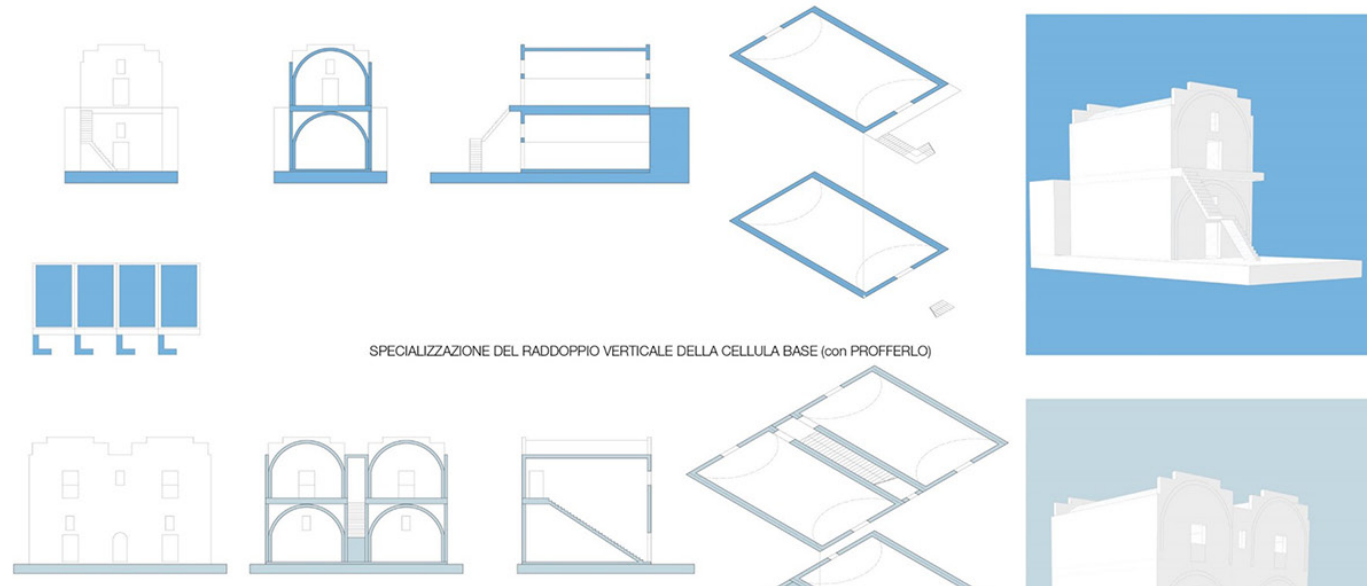
II Vicinato del Mondo. It is a way of being together no longer among a few families, but among people from different places. It no longer coincides with the horseshoe hollow on which the hypogea overlook, but with the whole of Matera, which today represents the arms of the ancient Sassi neighbourhood: the city is the source of a thousand-year-old culture from which new water flows. The first and new drop that could be able to generate the wave of change coincides with the last strip of terraces south of the Caveoso, that strip of the Sassi rich in the signs of its history. The small drop falls, moves a certain amount of volume, generates a perturbation: an infinity of concentric waves that propagate increasing their diameter. The drop is synonymous with water, excavation, system and community, words synthesis of the complex history of Matera. Four important concepts that demonstrate how man has been able for millennia to adapt to the environment in respect of this: man and nature are continuously interpenetrating (fig $\mid 0)$.

So how do we reconnect and sew what Casalnuovo has lost to the city plot? Two design strategies have been carried out: the first looks at the external-internal flow and the second at the internal flow from the city to via Casalnuovo.

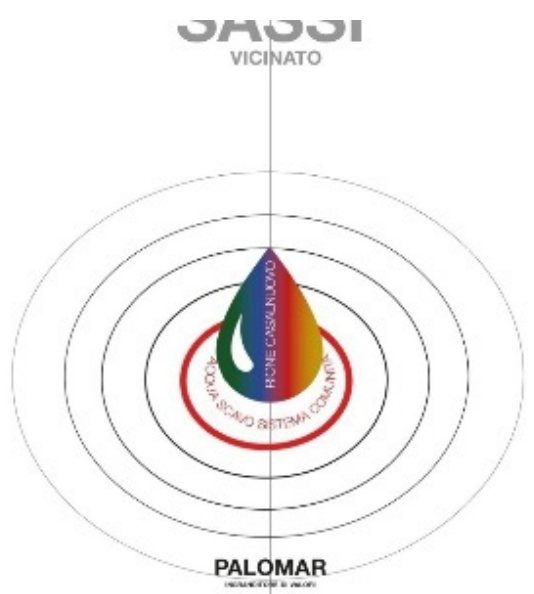

PALOMAR

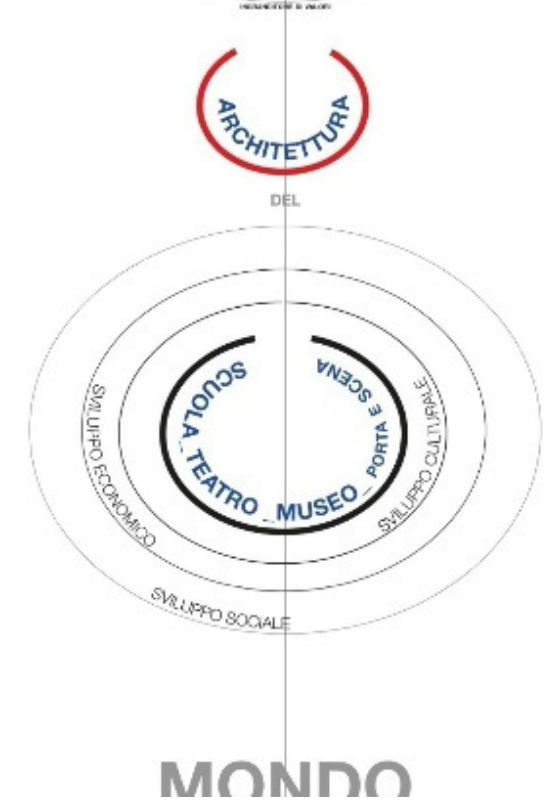




\section{Outer-interior flow: The Door}

With a view to a future expansion of the city in a southerly direction and an increasing number of visitors, Matera, lightening the tourist load that arrives in Piazza della Visitazione, can benefit from the construction of a new entrance to the Sassi: the southern gate, the beginning of the route of the ancient valleys. Strengthened by the future construction of the Appulo-Lucana railway line stop (at the Madonna delle Grazie Hospital) and by the possible arrangement of the area surrounding Villino Bronzini as a park, the idea of opening an access door to the Sassi on Via Casalnuovo, in addition to the canonical ones in the centre, is strategic, as well as an operation capable of bringing this southern wing of Matera back into the dynamics of the city's development. Between Via Lucana and the lower Casalnuovo 7 meters of difference in height prevent the passage of the flow of people: the solution is to cross from the inside the mass that separates the two floors in its height. A clear axis that introduces the flow of the 'communities of the world' directly on via Casalnuovo, directing it to the Sassi and to the discovery of these.

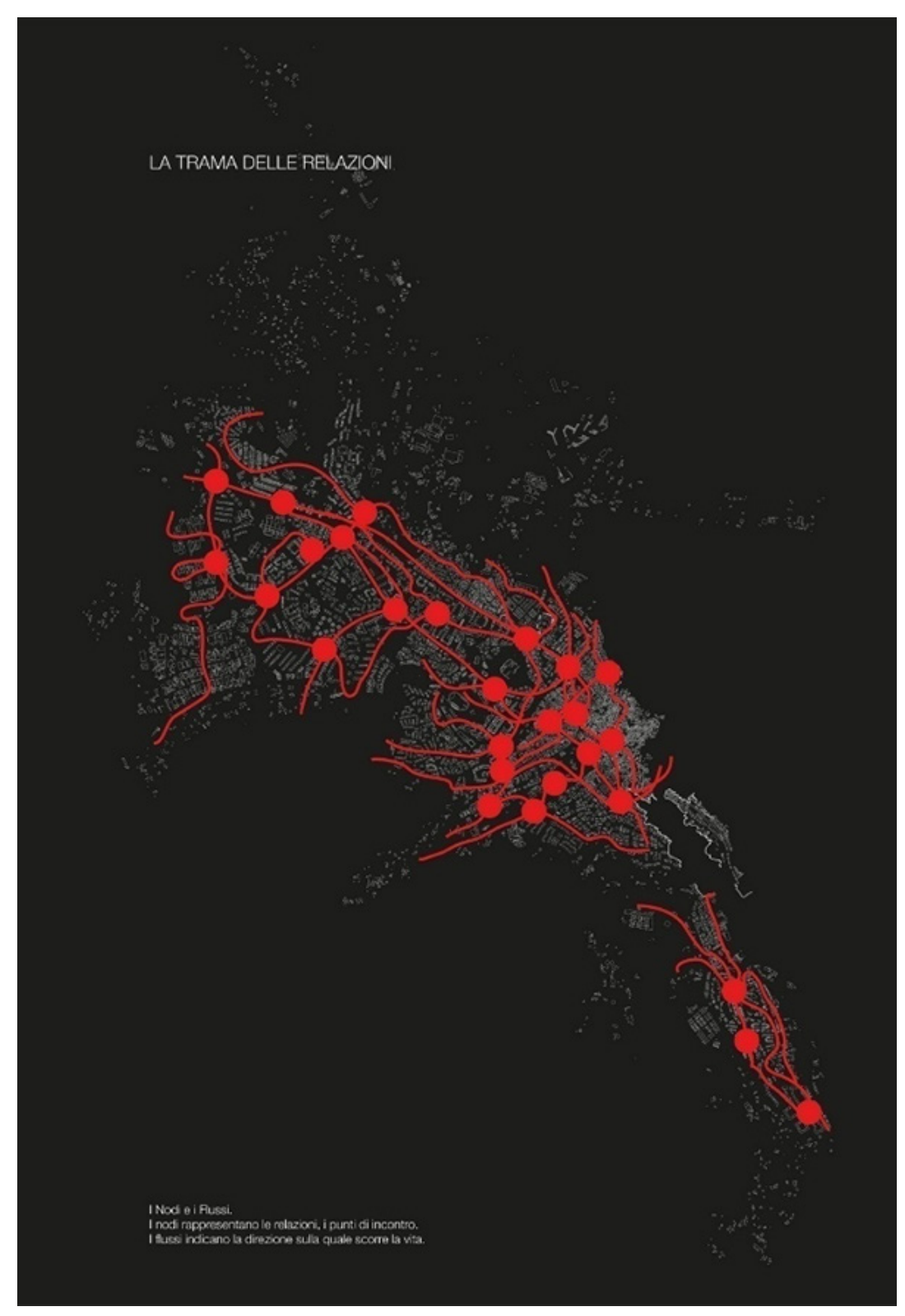




\section{Internal flow from the city to Via Casalnuovo: The Scene}

The mending of the other end of the 'Casalnuovo thread' can be done by intervening on the urban scene. Via Ridola, the beating heart of city life, is just a few metres away, yet it seems distant and unable to incorporate the long Via degli Albanesi to the rest of the city. In order for the flow, now that of visitors and now that of the inhabitants, to be motivated to go beyond the old grabiglione, there must be an attraction, a reason to extend the walk beyond Via Ridola. This is the fundamental principle of the Palomar projects that become the scene of the new promenade: numerous shops/shops are fixed on the ground floor, the houses are moved to the first floor in a completion of the long elevations of the street. The Palomar Museum distributes its numerous entrances, the Palomar School of Design fills the volume of the bare rustico contaminating the former oil mill below and the PalomarTheatre, at the height of the church of San Rocco, becomes a square, with the aim of creating an important cross connection hinge. The physical limit has a predominant role, so design principle becomes the choice of the void by drawing hollowed-out volume that gives to Via Lucana the feeling of openness. Thus the 'building wall' falls down and the modern city opens up to its past, leaving the eye to the possibility of reaching a new horizon (fig. I I).

It is these projects that, in accordance with the shape of the city's landscape and its wealth of resources, become an architectural interpretation of the values of Matera's identity.

\section{VIA LUCANA UN MURO SUL PAESAGGIO}
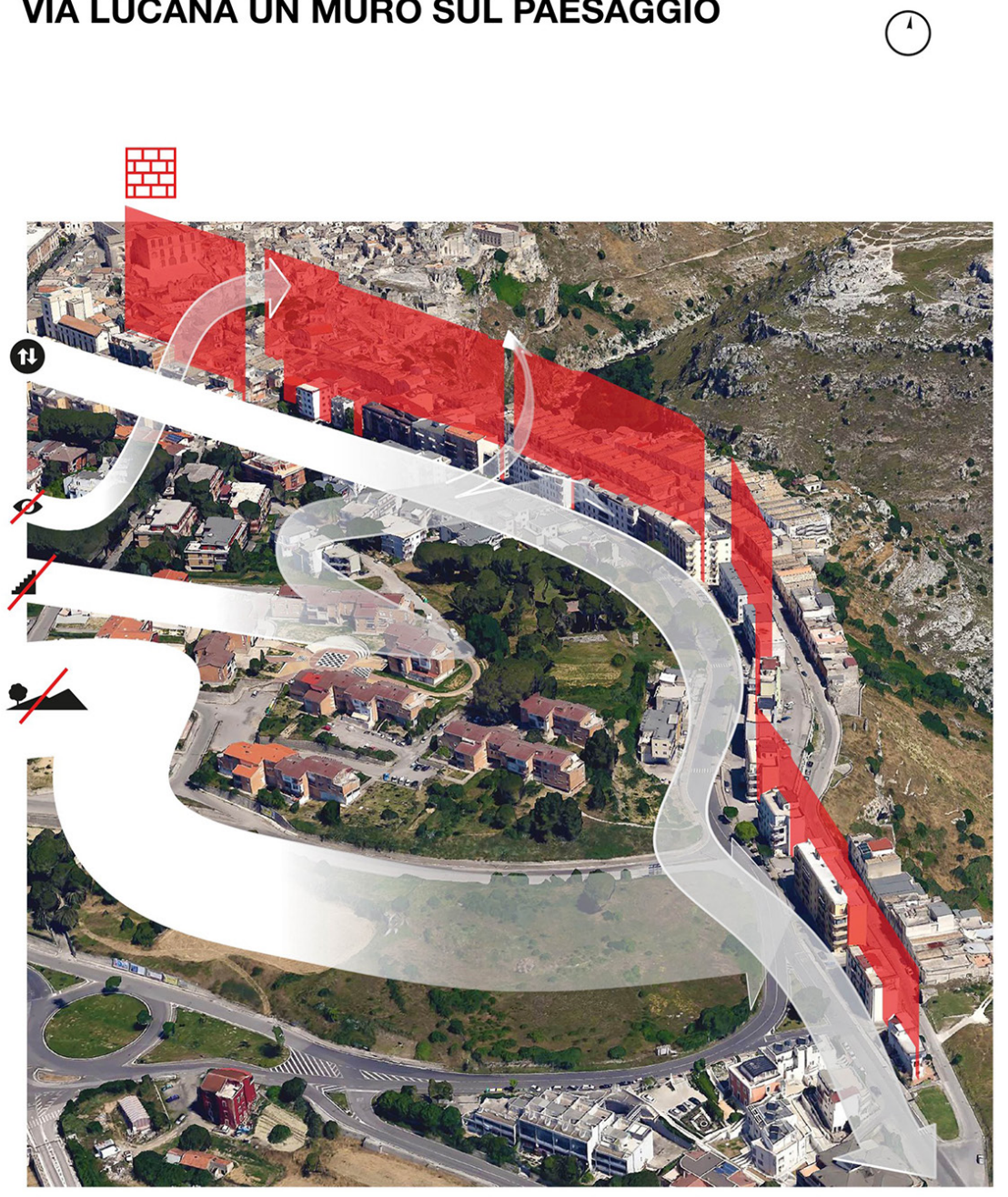
The scene of the new promenade is also composed of the horizontal plane of the street. The re-paving of the entire street is important both in giving homogeneity of intervention in a design discourse that starts at one end of the route and ends at the other, and in the redesign of a new street profile: the direction of travel becomes unique and the driveway section from a maximum width of 7 meters is reduced to 3 leaving more space for the sidewalks. The door and the scene are proposed as two possible ways of operating in an attempt both to sew this piece of the city to the edges of the nearby Via Lucana and Via Ridola, and to direct and let the communities of Matera live and not an experience and teaching inherent in the heart of the Sassi, the Casalnuovo district and the new Palomar projects that are carriers of the same ancient system of values (fig. 12).

The gaze is on the whole city, not with the aim of giving substance to a specific function, but to trigger a real change. In a changing scenario, at the dawn of a new Matera that opens its doors, not only to Europe, but also the whole world, a set of wider and more general choices and thoughts inevitably leads to a near and permanent development of the city itself.

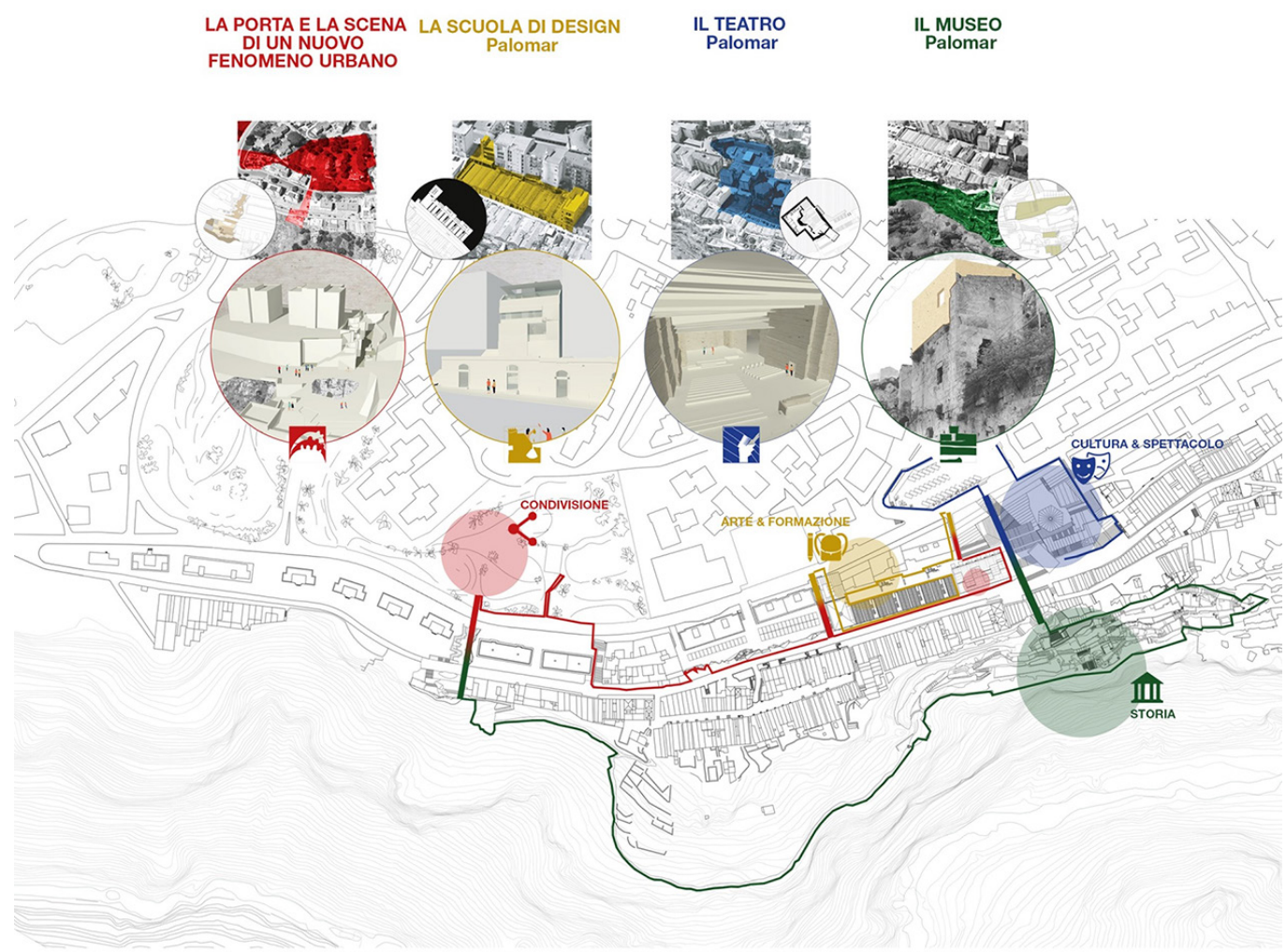

IL VICINATO DEL MONDO CONCEPT DI PROGETTO CONLA CREZIONE DI FUNZIONI PERMANENTI

[I] Master's thesis in Architecture. UNIBAS, DiCEM. Graduation Laboratory: Architettura ed eredità del costruito. "II Vicinato del Mondo. Design in the Urban Heritage: Rione Casalnuovo, via Casalnuovo, via Lucana. Matera." 20 I5. Internal lecturers: Prof. Arch. Antonio Conte, Prof. Arch. Angela Colonna. Outside lecturers: Arch. Luigi Acito, Arch. Lorenzo Rota. 


\section{References}

Calvino Italo (1990). Palomar. Milano: Mondadori.

Caniggia Gianfranco, Maffei Luigi (1979). Lettura dell'edilizia di base. Venezia: Marsilio.

Caniggia Gianfranco, Maffei Luigi (1984). Composizione architettonica e tipologia edilizia 2. II progetto nell'edilizia di base. Venezia: Marsilio.

Colonna Angela (20 I5). Genealogia del presente e storiografia dell'architettura. Potenza: Calebasse Edizioni.

Colonna Angela, Fiore Domenico (2012). Idee per un laboratorio partecipato. In Comune di Matera. Matera: i Sassi e il Parco delle chiese rupestri. Verso il piano di Gestione del sito UNESCO.

Colonna Angela, Fiore Domenico (20 I5). I Sassi e il Parco delle chiese rupestri di Matera patrimonio dell'umanità. Piano di Gestione 2014 - 2019. Matera: <http://www.comune.matera.it/piano-di-gestione-unesco>

Conte Antonio (2009). Comunità disegno. Laboratorio a cielo aperto di disegno e rappresentazione nei Sassi di Matera. Milano: Franco Angeli

Conte Antonio (20।4). La città scavata. Paesaggio di patrimoni tradizione e innovazione. Roma: Gangemi Editore.

Giuffrè Antonino, Carocci Caterina (1997). Codice di Pratica per la sicurezza e la conservazione dei Sassi di Matera. Matera: Edizioni La Bautta.

Koolhaas Rem (2006). Junkspace. Macerata: Quodlibet.

Rossi Aldo (2009). L'autobiografia scientifica. Milano: il Saggiatore.

Rossi Aldo, (2019). L'architettura della città. Milano: il Saggiatore.

Rota Lorenzo (20 I I). Matera Storia di una Città. Matera: Studiogiannatelli.

Strappa Giuseppe (1995). Unità dell'organismo architettonico, Note sulla formazione e trasformazione dei caratteri degli edifici. Bari: Edizioni Dedalo

\section{Authors}

Roberto Blasi, Università degli Studi della Basilicata, roberto.blasi@unibas.it

Maria Federica Lettini, Università degli Studi della Basilicata, federicalettini@gmail.com

Roberto Pedone, Università degli Studi della Basilicata, roberto, pedone@unibas.it

Margherita Tricarico, Università degli Studi della Basilicata, margherita.tricarico@unibas.it

To cite this chapter. Blasi Roberto, Lettini Maria Federica, Pedone Roberto, Tricarico Margherita (2020). Matera. La città del passato, la città de presente, la città del futuro. IIVicinato del Mondo/Matera. The city of the past, the city of the present, the city of the future.'II Vicinato del Mondo. In Arena A., Arena M., Brandolino R.G., Colistra D., Ginex G., Mediati D., Nucifora S., Raffa P. (a cura di). Connettere. Un disegno per annodare e tessere. Atti del $42^{\circ}$ Convegno Internazionale dei Docenti delle Discipline della Rappresentazione/Connecting. Drawing for weaving relationships. Proceedings of the 42th International Conference of Representation Disciplines Teachers. Milano: FrancoAngeli, pp. 933-956. 